\title{
Fatty Acid-Binding Protein 4 in Cardiovascular and Metabolic Diseases
}

\author{
Masato Furuhashi
}

Department of Cardiovascular, Renal and Metabolic Medicine, Sapporo Medical University School of Medicine, Sapporo, Japan

Fatty acid-binding proteins (FABPs), a family of lipid chaperones, contribute to systemic metabolic regulation via several lipid signaling pathways. Fatty acid-binding protein 4 (FABP4), known as adipocyte FABP (A-FABP) or aP2, is mainly expressed in adipocytes and macrophages and plays important roles in the development of insulin resistance and atherosclerosis in relation to metabolically driven low-grade and chronic inflammation, referred to as 'metaflammation'. FABP4 is secreted from adipocytes in a non-classical pathway associated with lipolysis and acts as an adipokine for the development of insulin resistance and atherosclerosis. Circulating FABP4 levels are associated with several aspects of metabolic syndrome and cardiovascular disease. Ectopic expression and function of FABP4 in cells and tissues are also related to the pathogenesis of several diseases. Pharmacological modification of FABP4 function by specific inhibitors, neutralizing antibodies or antagonists of unidentified receptors would be novel therapeutic strategies for several diseases, including obesity, diabetes mellitus, atherosclerosis and cardiovascular disease. Significant roles of FABP4 as a lipid chaperone in physiological and pathophysiological conditions and the possibility of FABP4 being a therapeutic target for metabolic and cardiovascular diseases are discussed in this review.

Key words: Adipocyte, Macrophage, Endothelium, Atherosclerosis, Insulin resistance, Adipokine, aP2, A-FABP, Mal1, E-FABP

\section{Introduction}

Several factors, including genetics, behavior and environment, cause visceral fat accumulation, which is associated with obesity-related metabolic disorders ${ }^{1,2)}$. In the adipose tissue of obesity, adipocytes and several immune cells, especially macrophages, interact with each other and induce insulin resistance, diabetes mellitus, dyslipidemia and hypertension, leading to the development of atherosclerosis ${ }^{2)}$ (Fig. 1). Adipose tissue can secrete several hormonal bioactive molecules called adipokines, including adiponectin, leptin, resistin and fatty acid-binding protein 4 (FABP4) $)^{2}$. It has recently been reported that FABP4, mainly expressed in adipocytes and macrophages, plays significant roles in the development of insulin resistance and atherosclerosis via both intracellular and extracellular effects $^{3-6)}$ (Fig. 1).

\section{Fatty Acid-Binding Proteins (FABPs)}

Fatty acid trafficking in cells affects many aspects of cellular function ${ }^{3)}$. Fatty acids act both as an energy source and as signals for metabolic regulations including gene expression, inflammatory and metabolic responses, and growth and survival pathways. Fatty acid-binding proteins (FABPs), a family of intracellular lipid chaperones, regulate lipid trafficking and responses in cells and are linked to metabolic and inflammatory pathways ${ }^{3-6)}$. FABPs are abundantly expressed $14-15-\mathrm{kDa}$ proteins that reversibly bind hydrophobic ligands, such as long-chain fatty acids and other lipids. It has been proposed that FABPs actively facilitate the transport of fatty acids to specific organelles in the cell for lipid oxidation in the mitochondrion or peroxisome, transcriptional regulation in the nucleus, signaling, trafficking and membrane synthesis in the endoplasmic reticulum (ER), and regula-

Address for correspondence: Masato Furuhashi, Department of Cardiovascular, Renal and Metabolic Medicine, Sapporo Medical University School of Medicine. S-1, W-16, Chuo-ku, Sapporo 060-8543, Japan E-mail: furuhasi@sapmed.ac.jp

Received: December 28, 2018 Accepted for publication: January 8, 2019

Copyright@2019 Japan Atherosclerosis Society

This article is distributed under the terms of the latest version of CC BY-NC-SA defined by the Creative Commons Attribution License. 


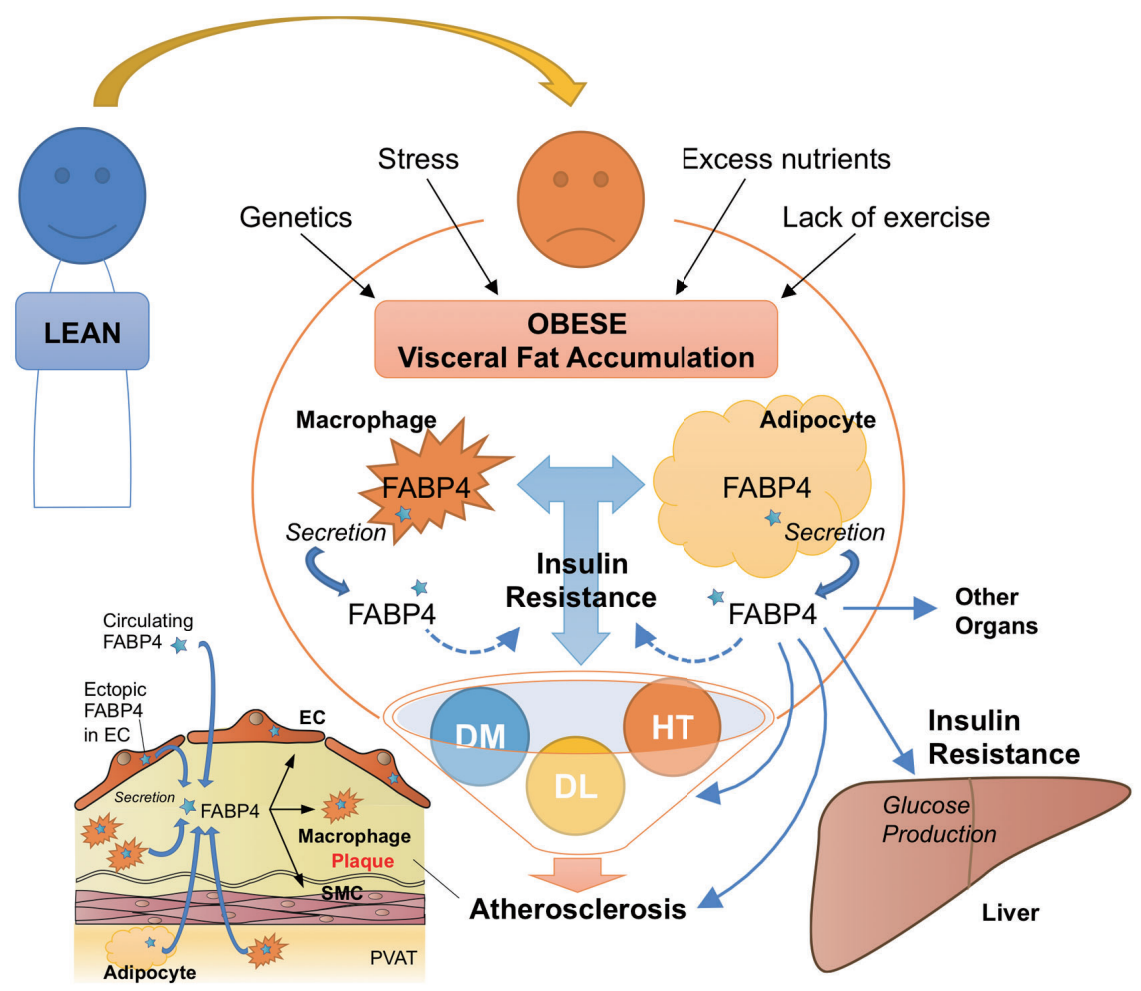

Fig. 1. FABP4-mediated insulin resistance and atherosclerosis in obesity

Several factors, including genetics, stress, excess nutrients and lack of exercise, induce obesity characterized by visceral fat accumulation. In adipose tissue, adipocytes and several immune cells, especially macrophages, interact with each other and induce insulin resistance, diabetes mellitus (DM), dyslipidemia (DL) and hypertension (HT), leading to the development of atherosclerosis. Fatty acid-binding protein 4 (FABP4), which is mainly expressed in adipocytes and macrophages, plays significant roles in the development of insulin resistance and atherosclerosis via both intracellular and extracellular effects.

EC, endothelial cell; PVAT, perivascular adipose tissue; SMC, smooth muscle cell.

tion of enzyme activity and storage as lipid droplets in the cytoplasm ${ }^{3)}$.

At least 9 different FABP isoforms have been identified. The FABP family includes liver (L-FABP/ FABP1), intestinal (I-FABP/FABP2), heart (H-FABP/ FABP3), adipocyte (A-FABP/FABP4/aP2), epidermal (E-FABP/FABP5/mal1), ileal (Il-FABP/FABP6), brain (B-FABP/FABP7), myelin (M-FABP/FABP8), and testis (T-FABP/FABP9) isoforms ${ }^{3)}$. FABPs have about $15 \%$ to $70 \%$ sequence identity between different isoforms and have almost the same three-dimensional structures showing a cap by the helix-loop-helix region and two orthogonal five-stranded $\beta$-sheets by a 10 -stranded anti-parallel $\beta$-barrel structure ${ }^{3,7)}$. The fatty acid-binding pocket is located inside the $\beta$-barrel. The opening of the binding pocket is framed on one side by the N-terminal helix-loop-helix cap domain, and usually one long-chain fatty acid can be bound to the interior cavity of FABPs except for FABP1, which can bind two fatty acids. Each FABP has different ligand selectivity and binding affinity for fatty acids because of structural differences ${ }^{3)}$.

\section{Expression of FABP4}

Expression of FABP4 is highly induced during adipocyte differentiation and is transcriptionally controlled by peroxisome proliferator-activated receptor (PPAR) $y$ agonists, fatty acids, insulin and dexamethasone $^{8-12)}$. Expression of FABP 4 is also induced during differentiation from monocytes to macrophages and by treatment with lipopolysaccharide (LPS), phorbol 12-myristate 13-acetate, PPAR $y$ agonists, oxidized low-density lipoprotein and advanced glycation end products ${ }^{13-17)}$. Similar to macrophages, monocytederived dendritic cells express FABP4 during differentiation ${ }^{18)}$. Conversely, treatment with omega-3 fatty acids $^{19)}$ and sitagliptin ${ }^{20)}$ decreases FABP4 expression in 3T3-L1 adipocytes. In macrophages, treatment with atorvastatin ${ }^{21)}$ and metformin ${ }^{22)}$ reduces FABP4 
expression. FABP4 also triggers the ubiquitination and subsequent proteasomal degradation of PPAR $y$ and consequently inhibits PPAR $y$-related functions, thereby providing a negative feedback loop ${ }^{23)}$.

The upstream of the 5' flanking region of the mouse FABP 4 gene contains a direct repeat-1 (DR-1)type PPAR response element (PPRE) at $-5.3 \mathrm{~kb}^{24,25)}$, a glucocorticoid response element (GRE) at -393 to $-385 \mathrm{bp}^{9)}$, a CCAAT/enhancer-binding protein (C/ EBP) $\alpha$ binding site at -149 to $-130 \mathrm{bp}^{26)}$, and an activator protein-1 (AP-1) site at -122 to $-116 \mathrm{bp}^{27)}$. A functionally significant genetic variation at the FABP 4 locus in humans, T-87C polymorphism, has been reported to result in decreased FABP4 expression in adipose tissue due to alteration of the C/EBP and reduced transcriptional activity of the FABP 4 promoter $^{28)}$.

FABP4 is also expressed in capillary and venous, but not arterial, endothelial cells in a normal condition $^{29)}$. Treatment with vascular endothelial growth factor (VEGF)-A via VEGF-receptor-2 or basic fibroblast growth factor (bFGF) induces FABP4 expression in endothelial cells ${ }^{29)}$, and FABP4 in endothelial cells promotes angiogenesis ${ }^{30)}$. Interestingly, cellular senescence and oxidative stress induce FABP 4 expression in microvascular endothelial cells ${ }^{31,32)}$. Furthermore, FABP4 is ectopically induced in injured arterial endothelial cells ${ }^{33,34)}$.

\section{Fatty Acid Affinity of FABP4}

In an assay for fatty acid-binding affinity, FABP4 generally had higher affinity and selectivity for longchain fatty acids than did albumin ${ }^{35)}$. Linoleic acid and $\alpha$-linolenic acid, essential polyunsaturated fatty acids, had the highest affinity for FABP 4 under a basal condition $^{35)}$, suggesting that transport of linoleic acid and $\alpha$-linolenic acid is a physiological role of FABP4. Under an oxidative condition, the affinity of FABP 4 for most of the fatty acids except for palmitic acid was decreased ${ }^{35)}$, indicating that palmitic acid, a saturated fatty acid, has relatively high affinity for FABP4 under a specific condition such as obesity-induced oxidative stress.

\section{Function of FABP4 in the Cell}

Similar to other FABPs, FABP4 is thought to carry fatty acids to several organelles in the cell such as the mitochondrion, peroxisome, ER and nucleus (Fig. 2). The primary sequence of FABP4 does not have a typical nuclear localization signal (NLS) or nuclear export signal (NES) as a potential functional domain $^{3)}$. However, the NLS and NES could be found in the three-dimensional structure of FABP $4^{36)}$. The NLS in FABP4 is activated by closure of the portal loop and perturbation of a swinging doorway region $^{37)}$. Non-activating ligands, such as oleic acid and stearic acid, protrude from the portal and prevent its closure, leading to masking of the NLS, while activating ligands, such as linoleic acid, troglitazone and anilinonaphthalene sulphonate, expose the NLS ${ }^{37)}$ (Fig. 2).

The sequence of FABP4 includes a hormonesensitive lipase (HSL) binding site ${ }^{38)}$. A direct proteinprotein interaction between FABP4 and HSL in adipocytes regulates lipolysis, and adipocytes in FABP4deficient mice have decreased lipolysis in vitro and in vivo $^{39,40)}$ (Fig. 2). FABP4 also interacts with comparative gene identification-58 (CGI-58), a potent co-activator of adipose triglyceride lipase (ATGL) that catalyzes the initiating step of intracellular triglyceride hydrolysis ${ }^{41)}$. Interestingly, during experimentally induced lipolysis, FABP4-deficient mice have reduced insulin secretion ${ }^{39)}$. As metabolic crosstalk between host and pathogen, Chlamydia pneumoniae, which needs to obtain nutrients such as ATP and lipids from host cells, infects and proliferates in adipocytes by inducing HSL-mediated lipolysis ${ }^{42)}$. Interestingly, Chlamydia pneumoniae exploits host FABP4 to facilitate fat mobilization and intracellular replication in adipocytes, suggesting that intracellular pathogens acquire energy via hijacking of the host lipid metabolism pathway ${ }^{42)}$.

As another protein-protein interaction, ligandbound FABP4 binds to Janus kinase 2 (JAK2) and attenuates its signaling ${ }^{43)}$. Phosphatase and tensin homolog on chromosome 10 (PTEN), which negatively regulates the phosphoinositide 3-kinase pathway, interacts with FABP4, possibly for regulation of lipid metabolism and adipocyte differentiation ${ }^{44)}$. Notably, PTEN-null keratinocytes showed an elevated expression of FABP4, suggesting that PTEN plays a role in the transcriptional regulation of FABP4 expres$\operatorname{sion}^{45)}$.

\section{Phenotype of FABP4 Deficiency}

FABP4-deficient mice with high-fat diet-induced and genetic obesity show reduced insulin resistance, but there is no effect of FABP4 on insulin sensitivity in lean mice ${ }^{46,47)}$. Knockdown of the Fabp 4 gene by RNA interference in dietary obese mice increases body weight and fat mass without significant changes in glucose and lipid homeostasis ${ }^{48)}$, being similar to the phenotype of FABP4 heterozygous knockout mice on a high-fat diet ${ }^{46)}$. The remaining expression of FABP4 might maintain some parts of FABP4 function. 


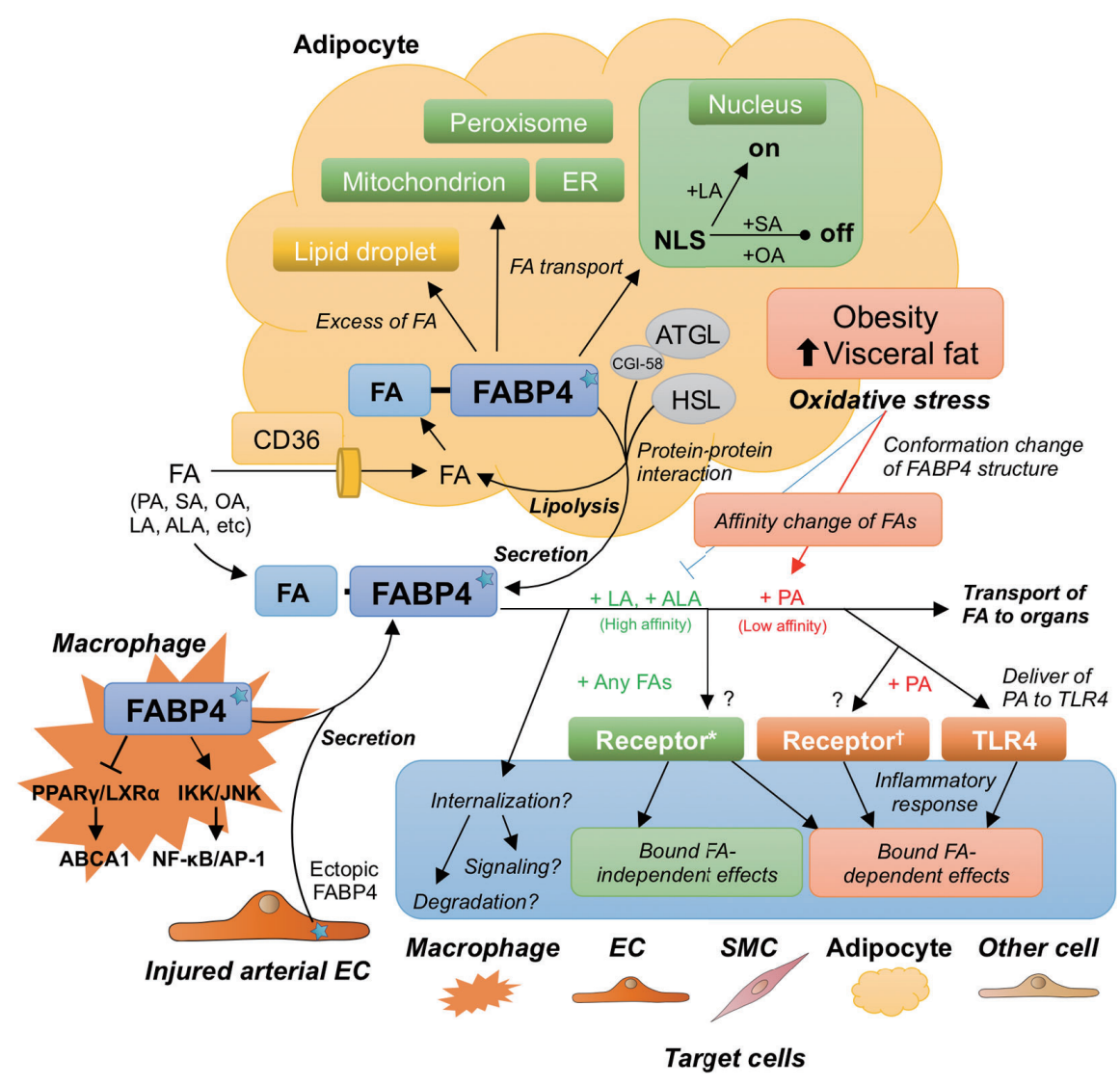

Fig. 2. Possible intracellular and extracellular functions of FABP4

FABP4 is abundant in the cytosolic fraction of adipocytes and can bind one long-chain fatty acid (FA), including palmitic acid (PA), stearic acid (SA), oleic acid (OA), linoleic acid (LA) or $\alpha$-linolenic acid (ALA). FABP4 facilitates the transport of FAs to specific organelles in the cell such as the mitochondrion, peroxisome, endoplasmic reticulum (ER) and nucleus, regulates enzyme activity, and stores excess FA as lipid droplets in adipocytes. LA-bound, but not SA- or OA-bound, FABP4 can be moved into the nucleus by unmasking of the nuclear localization signal (NLS). The protein-protein interactions of FABP4 with hormone-sensitive lipase (HSL) and comparative gene identification-58 (CGI58), a potent co-activator of adipose triglyceride lipase (ATGL), regulate intracellular triglyceride hydrolysis, and FABP4 is secreted from adipocytes in a non-classical pathway associated with lipolysis. FABP4 in macrophages inhibits the peroxisome proliferator-activated receptor $\gamma$ (PPAR $y$ )-liver X receptor $\alpha$ (LXR $\alpha)$-ATP-binding cassette A1 (ABCA1) pathway and induces inflammatory responses through activation of the inhibitor of nuclear kappa B kinase (IKK)-nuclear factor-kappa B (NF- $\kappa$ B) and c-Jun N-terminal kinase (JNK)-activator protein-1 (AP-1) pathways. FABP4 is ectopically induced in injured arterial endothelial cells (ECs). Macrophages and ECs can also secrete FABP4. Secreted FABP4 may act as a carrier of LA and ALA, essential polyunsaturated FAs, to organs because of high affinities for FABP4 under normal conditions. Circulating FABP4 may affect several responses in target cells, including macrophages, ECs, smooth muscle cells (SMCs), adipocytes and other cells, through unidentified receptor-mediated effects in bound FA-dependent and -independent manners and/or possible internalization of FABP4 into the cell. Obesity and increased visceral fat promote oxidative stress. An oxidative stress condition can induce conformation change of the FABP4 structure and decrease affinity of most of the FAs, except for PA, for FABP4. Under a specific condition such as obesity-induced oxidative stress, PA would have relatively high affinity for FABP4, leading to PA-dependent inflammatory responses through unidentified receptors of PA-bound FABP4 and/or delivery of PA to toll-like receptor 4 (TLR4).

Receptor*, an unidentified receptor of non-specific FA-bound FABP4. Receptor ${ }^{\dagger}$, an unidentified receptor of specific PA-bound FABP4.

FABP4 deficiency protects against atherosclerosis in apolipoprotein E (ApoE)-deficient mice ${ }^{13,}{ }^{49}$ ). FABP4 in macrophages increases accumulation of cholesterol ester and foam cell formation via inhibition of the PPAR $y$-liver X receptor $\alpha(\mathrm{LXR} \alpha)$-ATPbinding cassette A1 (ABCA1) pathway and induces inflammatory responses through activation of the inhibitor of nuclear kappa B kinase (IKK)-nuclear fac- tor-kappa $\mathrm{B}(\mathrm{NF}-\kappa \mathrm{B})$ and $\mathrm{c}$-Jun N-terminal kinase (JNK)- AP-1 pathways ${ }^{50,51)}$ (Fig. 2). Furthermore, the lack of FABP4 in macrophages decreases redox signaling and inflammasome activation via upregulation of uncoupling protein $2(\mathrm{UCP} 2)^{52)}$ and sirtuin 3 $(\text { SIRT3 })^{53)}$. FABP4 in dendritic cells also regulates the IKK-NF- $\kappa$ B pathway and $\mathrm{T}$ cell priming ${ }^{18)}$. 


\section{Secretion of FABP4}

FABP4 lacks a signal peptide in the $\mathrm{N}$-terminal sequence $^{3)}$, which is necessary for the classical secretory pathway, i.e., ER-Golgi-dependent secretion. However, FABP4 is secreted from adipocytes in a nonclassical secretion pathway associated with lipolysis, a series of intracellular triglyceride hydrolysis mediated by ATGL, HSL and monoacylglycerol lipase (MGL) ${ }^{54-56}$ (Fig.2). Secretion of FABP4 is also regulated by an intracellular calcium-dependent pathway ${ }^{57)}$. Furthermore, FABP4 is secreted partially by microvesicles derived from adipocytes ${ }^{55,58,59)}$, an established mechanism for unconventional secretion from adipocytes ${ }^{60)}$. However, the release of FABP4 via adipocyte-derived microvesicles is a small fraction and conveys a minor activity ${ }^{55,58)}$. In addition, unconventional secretion of FABP4 by endosomes and secretory lysosomes has recently been reported ${ }^{61)}$. It has also been confirmed that FABP4 is secreted from macrophages ${ }^{35)}$ and vascular endothelial cells ${ }^{34)}$ (Fig.2), though the predominant contributors of circulating FABP4 are adipocytes rather than macrophages and endothelial cell ${ }^{54,62)}$.

\section{FABP4 as a Bioactive Molecule}

FABP4 secreted from adipocytes, macrophages and endothelial cells may have bioactive effects since direct effects of exogenous FABP4 have been demonstrated in various types of cells. Exogenous FABP4 enhances hepatic glucose production in vivo and in vitro ${ }^{54)}$, induces endoplasmic reticulum stress in HepG2 liver cells ${ }^{63)}$, inhibits activation of endothelial nitric oxide synthase (eNOS) in vascular endothelial cells ${ }^{35)}$, increases proliferation/migration of vascular smooth muscle cells ${ }^{35)}$, decreases cardiomyocyte contraction in vitro ${ }^{58)}$, potentiated glucose-stimulated insulin secretion in pancreatic $\beta$ cells ${ }^{64)}$, and increases breast cancer cell proliferation ${ }^{65)}$.

Obesity and increased visceral fat have been reported to promote oxidative stress ${ }^{66)}$. FABP 4 prefers to bind linoleic acid and $\alpha$-linolenic acid for transport of essential polyunsaturated fatty acids in a normal condition, but the affinity of FABP 4 would be changed to prefer binding palmitic acid, a saturated fatty acid, probably via conformation change of FABP4 structure, in a condition of obesity-induced oxidative stress $^{35)}$ (Fig.2). Microarray analysis using macrophages treated with recombinant FABP 4 in the presence and absence of palmitic acid demonstrated fatty acid-dependent and -independent effects of exogenous FABP4 ${ }^{35)}$. Notably, treatment of macrophages with recombinant FABP4 in the presence, but not the absence, of palmitic acid significantly increased inflammatory responses, including chemokine signaling and $\mathrm{TNF} \alpha-\mathrm{NF}-\kappa \mathrm{B}$ signaling pathways ${ }^{35)}$. Furthermore, activation of palmitic acid-dependent inflammatory responses by FABP 4 was observed in not only in macrophages but also endothelial cells and vascular smooth muscle cells ${ }^{35)}$.

Taken together, circulating FABP4 secreted from adipocytes, macrophages and vascular endothelial cells seems to not only carry fatty acids to organs but also act as a bioactive molecule in several target cells, including macrophages, endothelial cells, smooth muscle cells, adipocytes and other cells (Fig.2). Because of the presence of fatty acid-dependent and -independent effects in cells, there would be both receptors for non-specific fatty acid-bound FABP4 and receptors for specific fatty acid, especially palmitic acid, -bound FABP4. However, possible receptors of FABP 4 have not been identified yet, though there was a report that cytokeratin 1 interacts with FABP4 on the endothelial cell membrane ${ }^{67)}$. Palmitic acid-bound FABP4 may just deliver palmitic acid to its receptor, toll-like receptor 4 (TLR4). Furthermore, it has been reported that a part of exogenous FABP4 internalizes into the cell ${ }^{34)}$, though whether internalized FABP4 has some functions for signaling or whether internalization is a process of degradation remains unclear (Fig. 2). It has recently been reported that cytokeratin 1 facilitates cellular uptake of exogenous FABP4 in endothelial cells, leading to regulation of oxidative and pro-inflammatory effects ${ }^{68)}$. It has also been shown that FABP4 binds to megalin, an endocytic receptor expressed in proximal tubule epithelial cells of the kidney, which plays a major role in reabsorption of proteins filtered through glomeruli ${ }^{69)}$.

\section{Circulating FABP4 Level}

The concentration of FABP 4 is highest among levels of FABP1 -5 under a physiological condition in a general population without medication ${ }^{70)}$. FABP4 level is significantly higher in females than in males, possibly due to the larger amount of body fat in females than in males since there is an independent and strong correlation between FABP 4 level and adiposity ${ }^{70,71)}$. In addition, androgen may partially contribute to the gender difference in serum FABP4 lev$\mathrm{els}^{72)}$. Circulating FABP4 levels are significantly correlated with norepinephrine levels during exercise testing ${ }^{73)}$, being consistent with FABP 4 secretion from adipocytes via $\beta$-adrenergic-mediated lipolytic mechanisms ${ }^{54-56)}$. Loss of body weight by exercise training ${ }^{74)}$ and bariatric surgery ${ }^{75,76)}$ induces a significant reduction in FABP 4 concentrations.

Gene and protein expression levels of FABP4 
have been reported to be higher in subcutaneous adipose tissue than in visceral adipose tissue of both lean and obese subjects ${ }^{77)}$, but associations of subcutaneous adipose tissue and visceral adipose tissue assessed by multidetector computed tomography with circulating FABP4 levels were reported to be almost the same ${ }^{78)}$. One possible reason for the discrepancy is that visceral adipose tissue is more metabolically active and sensitive to lipolysis than is subcutaneous adipose tissue ${ }^{79)}$, leading to the predominant contribution of visceral adipose tissue to the lipolysis-mediated secretion and circulating level of FABP4. The main source of circulating FABP4 is adipocytes rather than macrophages and endothelial cells ${ }^{54,62)}$. However, it has been reported that circulating FABP4 was detected in patients with lipodystrophy despite adipose tissue loss in contrast to other adipokines including leptin and adiponectin ${ }^{80)}$.

Multiplex proteomics demonstrated that FABP4 level was strongly associated with kidney function decline over a period of 5 years ${ }^{81)}$. Serum FABP4 level was shown to be negatively correlated with estimated glomerular filtration rate ${ }^{70}$, suggesting that FABP4 is eliminated from circulation mainly by renal clearance. It has recently been reported that circulating FABP 4 is eliminated by the kidney via glomerular filtration followed by megalin-mediated reabsorption ${ }^{69)}$. FABP4 level in hemodialysis patients with end-stage kidney disease was about 20-times higher than that in controls with normal renal function and was decreased by $57.2 \%$ after hemodialysis ${ }^{82}$.

Increased circulating FABP4 levels have been shown to be associated with obesity ${ }^{71)}$, metabolic syndrome $^{83)}$, insulin resistance ${ }^{70,84)}$, type 2 diabetes mellitus $^{85)}$, hypertension ${ }^{86)}$, dyslipidemia ${ }^{87)}$, atherosclerosis $^{88)}$, left ventricular diastolic dysfunction ${ }^{89)}$ and heart failure $^{90)}$ (Fig.3). Xanthine oxidoreductase (XOR), a rate-limiting and catalyzing enzyme of uric acid formation in purine metabolism, is involved in an increase in reactive oxygen species ${ }^{91)}$, and plasma XOR activity has been shown to be a novel biomarker of metabolic disorders ${ }^{92,93)}$. A cohort study demonstrated that plasma XOR activity is independently associated with levels of adipokines, including FABP ${ }^{94)}$. Circulating FABP4 is independently associated with the level of PCSK9, which binds to and degrades the lowdensity lipoprotein (LDL) receptor, suggesting associations with hypercholesterolemia and cardiovascular risk $^{95)}$. Furthermore, the basal FABP4 level is independently associated with change in carotid intima-media thickness, a marker of atherosclerosis, per year, indicating that FABP4 level predicts progress of atherosclerosis $^{96)}$. It has also been reported that serum FABP4 level predicts long-term cardiovascular events and mortality ${ }^{82,97-99)}$

Perivascular adipose tissue and epicardial fat have recently been proposed to influence vascular function and the pathogenesis of vascular disease ${ }^{100,101)}$. FABP4 mRNA expression in epicardial adipose tissue is profoundly increased compared with its expression in paraaortic adipose tissue in patients with metabolic syndrome ${ }^{102}$. FABP4, mainly derived from epicardial fat, is locally enrich in the pericardial cavity of cardiovascular disease patients ${ }^{103)}$. The coronary veno-arterial difference in FABP4 levels in the aortic root and coronary sinus was shown to be an independent predictor of the severity of coronary stenosis after adjustment of conventional risk factors ${ }^{35)}$. FABP 4 levels are significantly elevated during the early hours after onset of acute myocardial infarction and are robustly increased in out-of-hospital cardiac arrest survivors, probably due to rapid lipolytic release of FABP 4 from epicardial fat by adrenergic overdrive that accompanies acute cardiovascular disease ${ }^{104)}$.

Several drugs can modify circulating FABP4 levels (Fig. 3). Treatment with atorvastatin ${ }^{105}$, a hydroxymethylglutaryl-CoA reductase inhibitor, several angiotensin II receptor blockers ${ }^{106)}$, omega-3 fatty acid ethyl esters containing eicosapentaenoic acid and docosahexaenoic acid ${ }^{19)}$, and sitagliptin ${ }^{20)}$, a dipeptidyl peptidase- 4 inhibitor, reduces FABP 4 concentrations. On the other hand, treatment with pioglitazone, a PPAR $y$ agonist known as an insulin-sensitizing thiazolidinedione, increases FABP 4 levels ${ }^{107)}$, presumably due to direct activation of PPAR $y$ since the FABP4 gene promoter includes the PPRE ${ }^{24,25)}$. Treatment with canagliflozin, a sodium-glucose cotransporter 2 (SGLT2) inhibitor, paradoxically increased serum FABP4 level in some diabetic patients despite amelioration of glucose metabolism and adiposity reduction, possibly via induction of catecholamine-induced lipolysis in adipocytes, and patients in whom FABP4 level was increased by canagliflozin had significantly smaller improvements of insulin resistance and hemoglobin Alc than did patients with decreased FABP4 level ${ }^{108)}$. The increased FABP4 induced by PPAR $y$ agonists or SGLT2 inhibitors may act as a carrier of linoleic acid and $\alpha$-linolenic acid, as a physiological function. Therefore, it is important to enforce diet therapy for reducing accumulation of visceral fat and to prevent binding of FABP 4 to palmitic acid, especially in the treatment with a PPAR $y$ agonist and/or an SGLT2 inhibitor.

\section{Ectopic Expression of FABP4}

FABP4 is expressed in endothelial cells of capillaries and small veins but not arteries under a physio- 


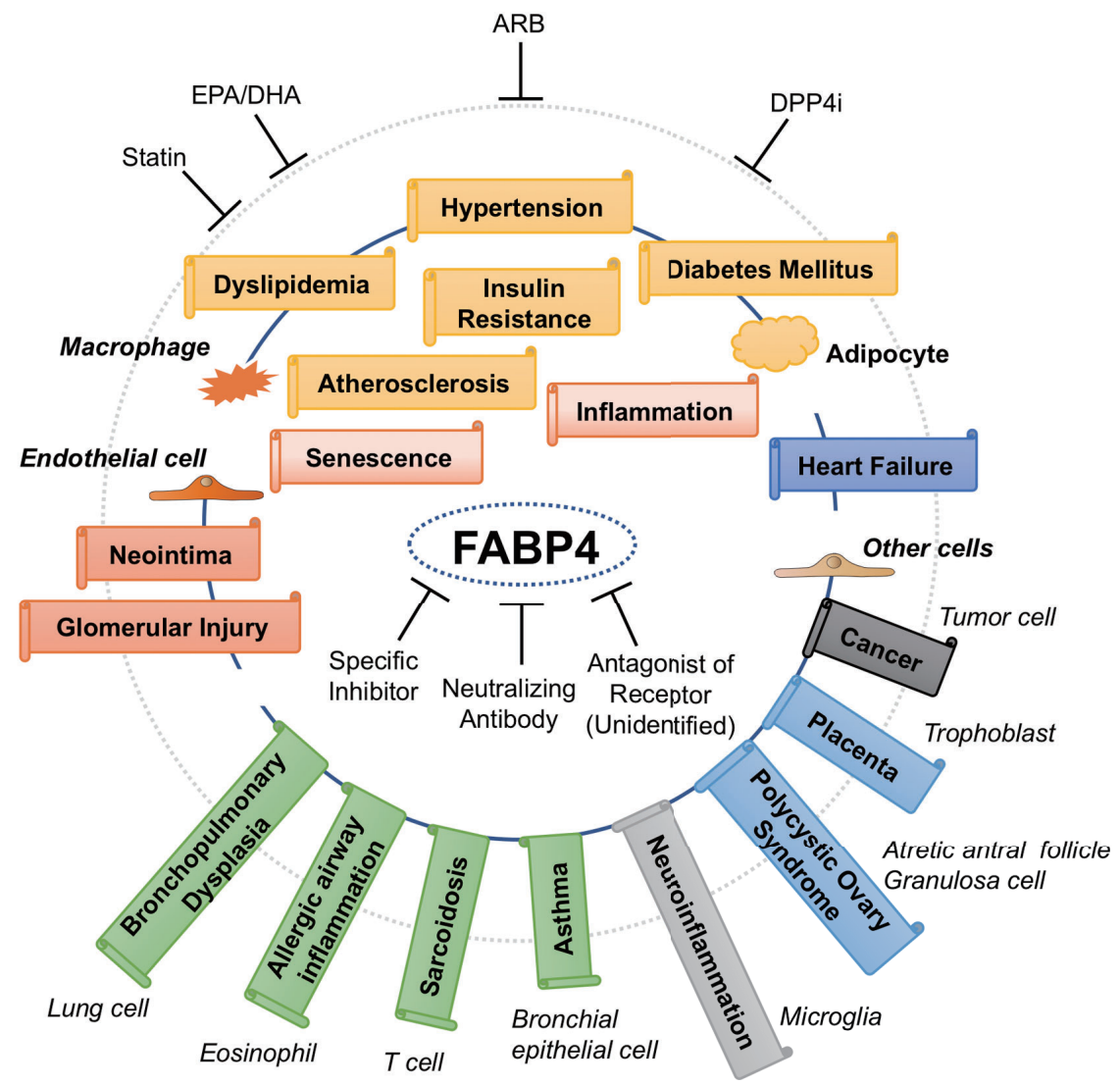

Fig. 3. Chain of FABP4-associated pathological conditions

FABP4 is expressed not only in adipocytes and macrophages but also in several types of tissues and cells under physiological and pathophysiological conditions and may contribute to several aspects of metabolic and cardiovascular diseases as well as renal, respiratory, neurological, gynecological and oncological diseases. Several drugs, including a statin, eicosatetraenoic acid (EPA)/ docosahexaenoic acid (DHA) agent, angiotensin II receptor blocker (ARB) and dipeptidyl peptidase 4 inhibitor (DPP4i), can decrease FABP4 levels. Specific inhibitors and neutralizing antibodies of FABP4 and antagonists of unidentified FABP4 receptors may be candidates of therapeutic strategies for several FABP4-associated diseases.

logical condition ${ }^{29)}$. FABP4 in capillary endothelial cells is involved in transendothelial fatty acid transport into fatty acid-consuming organs ${ }^{109)}$. FABP 4 is ectopically induced in regenerated arterial endothelial cells after endothelial balloon denudation ${ }^{33)}$ and wireinduced vascular injury ${ }^{34)}$. Neointima formation after wire-induced vascular injury is significantly decreased in FABP4-defficient mice compared with that in wildtype mice ${ }^{34)}$. Intermittent hypoxia also increases the expression of FABP4 in human aortic endothelial cells ${ }^{110)}$. FABP4 is expressed in the aortic endothelium of old, but not young, ApoE-deficient atherosclerotic mice, and chronic treatment with BMS309403, a small molecule FABP4 inhibitor, significantly improves endothelial dysfunction in old ApoE-deficient mice ${ }^{111)}$. Both FABP4 and FABP5 are also involved in cellular senescence of vascular endothelial cells $^{31,32)}$ (Fig. 3). FABP4 secreted from vascular endothelial cells increases gene expression of inflammatory cytokines in cells, promotes proliferation and migration of vascular smooth muscle cells, and decreases phosphorylation of eNOS in vascular endothelial cells, which are attenuated in the presence of an anti-FABP4 antibody ${ }^{34)}$. Ectopic expression of FABP4 under a pathological condition, but not physiological expression of FABP4, in the endothelium may contribute to the pathogenesis of atherosclerosis and vascular injury.

In normal kidneys, FABP4 is expressed in endothelial cells of the tubulointerstitial peritubular capillary and vein in both the cortex and medulla, but not in glomerular or arterial endothelial cells, under a normal physiological condition ${ }^{29)}$. Ectopic expression of FABP4 in endothelial cells and macrophages of the glomerulus is associated with progression of protein- 
uria and renal dysfunction ${ }^{112)}$ (Fig.3). It has also been reported that FABP4 is expressed in glomerular mesangial cells of diabetic nephropathy ${ }^{113}$. Among the FABPs, FABP1 (L-FABP) is expressed in proximal tubular epithelial cells in the kidney, and urinary FABP1 reflects damage of proximal tubular epithelial cells ${ }^{114)}$. Urinary FABP 4 has been proposed to be a novel biomarker reflecting glomerular damage ${ }^{115)}$, and determination of both FABP1 and FABP4 in urine may enable better characterization of renal injury.

Evidence for the involvement of FABP4 in several kinds of diseases and conditions has been accumulating $^{3-6)}$ (Fig.3). FABP4 has been shown to be expressed in lung and bronchoalveolar cells in bronchopulmonary dysplasia ${ }^{116)}$, lung lavage cells in sarcoidosis ${ }^{117)}$, bronchial epithelial cells ${ }^{118)}$ and vascular endothelial cells ${ }^{119)}$ in asthma, eosinophils in allergic airway inflammation ${ }^{120)}$, microglia cells in neuroinflammation ${ }^{121)}$, resident macrophages/microglial cells and endothelial cells of the hyaloid vasculature in the immature retina of proliferative retinopathy ${ }^{122)}$, pulmonary artery endothelial cells in pulmonary thromboembolism ${ }^{123)}$, hepatocytes in liver ischemia/reperfusion injury ${ }^{124)}$, human placental trophoblasts during placental development ${ }^{125)}$, and granulosa cells of the ovary in polycystic ovary syndrome ${ }^{126,127)}$. Furthermore, FABP 4 has been detected in human ovarian cancer cells at the adipocyte-tumor cell interface, and FABP4 deficiency in mice substantially impaired metastatic tumor growth ${ }^{128)}$. FABP4 can substantially increase the metastatic potential of ovarian cancer cells ${ }^{129)}$. FABP4 expression has also been detected in lipoblasts of lipoblastoma and liposarcoma ${ }^{130)}$, glioblastoma ${ }^{131)}$ and urothelial carcinomas ${ }^{132)}$, breast cancer $^{133,134)}$, prostate cancer ${ }^{135)}$, hepatocytes ${ }^{136,137)}$ and hepatic stellate cells ${ }^{138)}$ in hepatocellular carcinoma, oral and cervical squamous cell carcinoma ${ }^{139,140)}$ and non-small cell lung cancer ${ }^{141)}$.

\section{FABP4 as a Therapeutic Target}

Several series of FABP 4 inhibitors have been synthesized $^{3,142-144)}$. The specific FABP4 inhibitor BMS309403 is an orally active small molecule that interacts with the fatty acid-binding pocket within the interior of FABP4 to inhibit binding of endogenous fatty acids ${ }^{3,142,143)}$. Treatment with BMS309403 has been shown to improve insulin resistance, diabetes mellitus, fatty liver disease and atherosclerosis in experimental model $^{143)}$, indicating that chemical inhibition of FABP4 could be a therapeutic strategy against several aspects of metabolic syndrome (Fig. 3). Recent studies have also demonstrated that neutralization of secreted FABP4 with an antibody to FABP4 could be a feasible approach for treatment of insulin resistance, type 2 diabetes mellitus and vascular injury ${ }^{34,54,145,146)}$ (Fig.3). Furthermore, treatment with antagonists of receptors for $\mathrm{FABP} 4$, especially PA-bound FABP4, would be a novel therapeutic strategy, though receptors for FABP 4 have not been identified yet.

\section{FABP5 as an FABP4-Related Lipid Chaperone}

FABP5, another FABP known as epidermal FABP (E-FABP), psoriasis-associated FABP (PAFABP) or mal1, is expressed most abundantly in epidermal cells of the skin but is also present in several tissues and cells including adipocytes ${ }^{3)}$. FABP 4 and FABP5 have $52 \%$ amino acid similarity and bind to several fatty acids with similar affinity and selectivity. The amount of FABP4 in adipocytes is about 100fold larger than that of FABP5 in adipocytes ${ }^{147)}$. Both FABP4 and FABP5 are also expressed in macrophages and dendritic cells, though the amount of FABP 4 in adipocytes is about 10,000-fold larger than that in macrophages ${ }^{118)}$. The stoichiometry of FABP4 and that of FABP5 are nearly equal in macrophages under physiological conditions ${ }^{13)}$. FABP4 deficiency induces a strong compensatory increase of FABP5 in adipose tissue but not in macrophages or dendritic cells ${ }^{13}, 18,46$ ). Other than adipocytes and macrophages, FABP5 is coexpressed with FABP4 in microvascular endothelial cells in the heart and kidney ${ }^{29,109)}$ and even in endothelial cells of larger blood vessels ${ }^{148)}$. Similar to FABP4, FABP5 facilitates transendothelial transport of fatty acids into fatty acid-consuming organs ${ }^{109)}$.

Expression of FABP5 in macrophages is increased by treatment with toll-like receptor (TLR) agonists: LPS, a TLR4 agonist, and zymosan, a fungal product that activates TLR2 ${ }^{149)}$. Expression of FABP 5 in endothelial cells is induced by cellular senescence and $\mathrm{H}_{2} \mathrm{O}_{2}$-induced oxidative stress ${ }^{31,32)}$. In contrast to FABP4, FABP5 is not induced by VEGF-A or bFGF in endothelial cells ${ }^{148)}$. FABP5, similar to FABP4, in endothelial cells promotes angiogenic responses, but FABP5 can also exert opposing effects on endothelial survival, indicating that the balance between FABP4 and FABP5 in endothelial cells may be important for the regulation of angiogenic versus quiescent phenotypes in blood vessels ${ }^{148)}$.

FABP5 transgenic mice in adipose tissue on a high-fat diet show enhanced basal and hormone-stimulated lipolysis and reduced insulin sensitivity ${ }^{150,151)}$. On the other hand, FABP5 deficiency mildly increases systemic insulin sensitivity in dietary and genetic obesity mouse models ${ }^{150}$. Ablation of FABP5 suppresses 
atherosclerosis in LDL receptor-deficient mice on a western-style hypercholesterolemic diet, and the antiatherosclerotic effect of FABP5 deletion is associated with reduction of inflammatory response ${ }^{152}$.

Secretome analyses showed that FABP5 is also secreted from cells ${ }^{62,111,153)}$, though the mechanism remains unclear. Transcriptome and metabolome analyses showed that exogenous FABP 4 and FABP5 differentially affect transcriptional and metabolic regulation in adipose-derived stem cells near adipocytes ${ }^{153)}$. Circulating FABP5 has been reported to be detected at levels of about one tenth or less of circulating FABP 4 concentrations, and FABP5 levels are associated with components of metabolic syndrome, although the correlation is not as strong as that of FABP $4^{70,154)}$. Interestingly, the concentration of FABP5, but not FABP4, is negatively and independently correlated with cholesterol efflux capacity from macrophages, the first step in the reverse cholesterol transport pathway, suggesting a potential biomarker for residual risk of atherosclerosis $^{155)}$.

\section{Phenotype of Combined Deficiency of FABP4 and FABP5}

Mice with combined deficiency of FABP 4 and FABP5 $\left(\right.$ Fabp $\left.^{4^{-/-}} \mathrm{Fabp}^{-/-}\right)$exhibit protection against type 2 diabetes, fatty liver disease and atherosclerosis more than do FABP4- or FABP5-deficient mice ${ }^{156-158)}$. The effects of FABP4 and FABP5 on atherosclerosis are mainly due to their actions in macrophages ${ }^{13,152)}$. On the other hand, actions of FABP 4 and FABP5 in adipocytes and those in macrophages have distinct roles in regulation of insulin sensitivity through metabolic and inflammatory responses ${ }^{62)}$. Calorie restriction prevents age-related metabolic disease and extends life span ${ }^{159)}$, and it shares many molecular features in combined deficiency of FABP 4 and FABP5, but Fabp $4^{-/-} \mathrm{Fabp}^{-/-}$mice do not have increased longevity ${ }^{160)}$, indicating that extension of a metabolically healthy span in the absence of calorie restriction can be uncoupled from lifespan. It has also been demonstrated that Fabp $4^{-1-} \mathrm{Fabp} 5^{-/-}$mice have defective uptake of fatty acid via capillary endothelial cells of the heart and skeletal muscle with compensatory upregulation of glucose consumption in those tissues during fasting ${ }^{161)}$. Furthermore, Fabp $4^{-/-} F a b p 5^{-/-}$ mice show impaired thermogenesis after cold exposure during fasting ${ }^{162)}$.

Lipidomic analyses showed increased de novo lipogenesis by induction of stearoyl-CoA desaturase-1 (SCD-1) and fatty acid synthase in adipose tissue of Fabp $4^{-1-} \mathrm{Fabp}^{-1-}$ mice, leading to identification of increased palmitoleate (C16:1n7), an unsaturated free fatty acid, as an adipose tissue-derived lipid hormone, referred to as 'lipokine', that can decrease fatty liver and increase glucose uptake in skeletal muscle ${ }^{163)}$. Deletion of FABP4 in macrophages also increases de novo lipogenesis pathways through $\mathrm{LXR} \alpha$-mediated SCD-1 activation, resulting in production of palmitoleate and resistance to ER stress ${ }^{164)}$. Unsaturated fatty acids including palmitoleate modulate histone deacetylation, resulting in decreased basal and LPSinduced expression levels of FABP4 in macrophages ${ }^{165)}$. Treatment with palmitoleate prevents atherosclerosis in ApoE-deficient mice in relation to reduced ER stress and inflammasome activation ${ }^{166)}$. In a human study, palmitoleate level was positively correlated with insulin sensitivity assessed by euglycemichyperinsulinemic clamp studies after adjustment of age, gender and adiposity ${ }^{167)}$. The level of the trans isomer of palmitoleate, an exogenous source of $\mathrm{C} 16: 1 \mathrm{n} 7$, was associated with lower insulin resistance and lower incidence of diabetes mellitus ${ }^{168)}$.

\section{Perspectives and Conclusion}

FABP4 is mainly expressed in adipocytes and macrophages and plays important roles in the development of insulin resistance and atherosclerosis in relation to metabolically driven low-grade and chronic inflammation, referred to as 'metaflammation' ${ }^{2)}$ (Fig. 1). FABP4 is involved in the regulation of inflammatory and metabolic processes in target cells (Fig. 2). The presence of FABP4 in cells may be beneficial for storing energy in adipocytes, for acting on an immune response in macrophages against pathogens, and for trafficking of fatty acids in capillary endothelial cells. Additionally, secreted FABP4 in association with lipolysis during fasting may regulate hepatic glucose production for survival in a famine. In the contemporary life-style with excessive caloric intake and decreased energy expenditure, the presence and induction of FABP4 or enhanced secretion of conformation-changed FABP4, which can bind to palmitic acid with a relatively high affinity ${ }^{35)}$, may be rather disadvantageous for regulating inflammatory or metabolic homeostasis. In such conditions, inhibition of FABP4, neutralization/elimination of secreted FABP4 or the use of possible antagonists for unidentified receptors of FABP 4 could be an effective therapeutic strategy against metabolic and cardiovascular diseases and possibly other diseases (Fig.3). Further studies are obviously needed to investigate whether chemical or other types of inhibition/neutralization of FABP4 and blocking receptors of FABP4 can be safely used in humans and to show the efficacy of agents for metabolic and cardiovascular diseases. Furthermore, other 
than FABP4, several types of FABP inhibitors have been identified ${ }^{169,170)}$, but there have been few detailed examinations using those inhibitors in in vivo and in vitro studies. Not only FABP4 but also other FABPs, including FABP5, may offer targeting opportunities as a class for prevention or treatment of other diseases. Much work is still needed to determine the precise applications and indications for other isoforms.

\section{Acknowledgements}

In relation to this review article, M.F. has been supported by grants from JSPS KAKENHI, MEXT Translational Research Network Program, Uehara Memorial Foundation, SENSHIN Medical Research Foundation, Japan Diabetes Foundation, Takeda Medical Research Foundation, Ono Medical Research Foundation, Takeda Science Foundation, Akiyama Life Science Foundation, Yamaguchi Endocrine Research Foundation, Naito Foundation Natural Science Scholarship, Suhara Memorial Foundation, Kondou Kinen Medical Foundation and Terumo Foundation for Life Science and Arts. The author is grateful to group members of our department for their scientific contribution and is deeply honored to receive Yuichiro Goto Award of the Japan Atherosclerosis Society in 2018. The author also regrets the inadvertent omission of many important references due to space limitations.

\section{Conflict of Interest}

None.

\section{References}

1) Gregor MF, Hotamisligil GS: Inflammatory mechanisms in obesity. Annu Rev Immunol, 2011; 29: 415-445

2) Hotamisligil GS: Inflammation, metaflammation and immunometabolic disorders. Nature, 2017; 542: 177 185

3) Furuhashi M, Hotamisligil GS: Fatty acid-binding proteins: role in metabolic diseases and potential as drug targets. Nat Rev Drug Discov, 2008; 7: 489-503

4) Furuhashi M, Ishimura S, Ota H, Miura T: Lipid chaperones and metabolic inflammation. Int J Inflam, 2011; 2011: 642612

5) Furuhashi M, Saitoh S, Shimamoto K, Miura T: Fatty Acid-Binding Protein 4 (FABP4): Pathophysiological Insights and Potent Clinical Biomarker of Metabolic and Cardiovascular Diseases. Clin Med Insights Cardiol, 2014; 8: 23-33

6) Hotamisligil GS, Bernlohr DA: Metabolic functions of FABPs--mechanisms and therapeutic implications. Nat Rev Endocrinol, 2015; 11: 592-605

7) Chmurzynska A: The multigene family of fatty acid- binding proteins (FABPs): function, structure and polymorphism. J Appl Genet, 2006; 47: 39-48

8) Amri EZ, Bertrand B, Ailhaud G, Grimaldi P: Regulation of adipose cell differentiation. I. Fatty acids are inducers of the aP2 gene expression. J Lipid Res, 1991; 32: 1449-1456

9) Cook JS, Lucas JJ, Sibley E, Bolanowski MA, Christy RJ, Kelly TJ, Lane MD: Expression of the differentiation-induced gene for fatty acid-binding protein is activated by glucocorticoid and cAMP. Proc Natl Acad Sci U S A, 1988; 85: 2949-2953

10) Distel RJ, Robinson GS, Spiegelman BM: Fatty acid regulation of gene expression. Transcriptional and posttranscriptional mechanisms. J Biol Chem, 1992; 267: 5937-5941

11) Kletzien RF, Foellmi LA, Harris PK, Wyse BM, Clarke SD: Adipocyte fatty acid-binding protein: regulation of gene expression in vivo and in vitro by an insulin-sensitizing agent. Mol Pharmacol, 1992; 42: 558-562

12) Melki SA, Abumrad NA: Expression of the adipocyte fatty acid-binding protein in streptozotocin-diabetes: effects of insulin deficiency and supplementation. J Lipid Res, 1993; 34: 1527-1534

13) Makowski L, Boord JB, Maeda K, Babaev VR, Uysal KT, Morgan MA, Parker RA, Suttles J, Fazio S, Hotamisligil GS, Linton MF: Lack of macrophage fatty-acidbinding protein $\mathrm{aP} 2$ protects mice deficient in apolipoprotein E against atherosclerosis. Nat Med, 2001; 7: 699-705

14) Fu Y, Luo N, Lopes-Virella MF, Garvey WT: The adipocyte lipid binding protein (ALBP/aP2) gene facilitates foam cell formation in human THP-1 macrophages. Atherosclerosis, 2002; 165: 259-269

15) Kazemi MR, McDonald CM, Shigenaga JK, Grunfeld C, Feingold KR: Adipocyte fatty acid-binding protein expression and lipid accumulation are increased during activation of murine macrophages by toll-like receptor agonists. Arterioscler Thromb Vasc Biol, 2005; 25: 1220-1224

16) Pelton PD, Zhou L, Demarest KT, Burris TP: PPARgamma activation induces the expression of the adipocyte fatty acid binding protein gene in human monocytes. Biochem Biophys Res Commun, 1999; 261: 456-458

17) Fu Y, Luo N, Lopes-Virella MF: Oxidized LDL induces the expression of ALBP/aP2 mRNA and protein in human THP-1 macrophages. J Lipid Res, 2000; 41: 2017-2023

18) Rolph MS, Young TR, Shum BO, Gorgun CZ, SchmitzPeiffer C, Ramshaw IA, Hotamisligil GS, Mackay CR: Regulation of dendritic cell function and T cell priming by the fatty acid-binding protein AP2. J Immunol, 2006; 177: 7794-7801

19) Furuhashi M, Hiramitsu S, Mita T, Omori A, Fuseya T, Ishimura S, Watanabe Y, Hoshina K, Matsumoto M, Tanaka M, Moniwa N, Yoshida H, Ishii J, Miura T: Reduction of circulating FABP4 level by treatment with omega-3 fatty acid ethyl esters. Lipids Health Dis, 2016; 15: 5

20) Furuhashi M, Hiramitsu S, Mita T, Fuseya T, Ishimura S, Omori A, Matsumoto M, Watanabe Y, Hoshina K, Tanaka M, Moniwa N, Yoshida H, Ishii J, Miura T: 
Reduction of serum FABP4 level by sitagliptin, a DPP-4 inhibitor, in patients with type 2 diabetes mellitus. J Lipid Res, 2015; 56: 2372-2380

21) Llaverias G, Noe V, Penuelas S, Vazquez-Carrera M, Sanchez RM, Laguna JC, Ciudad CJ, Alegret M: Atorvastatin reduces CD68, FABP4, and HBP expression in oxLDL-treated human macrophages. Biochem Biophys Res Commun, 2004; 318: 265-274

22) Song J, Ren P, Zhang L, Wang XL, Chen L, Shen YH: Metformin reduces lipid accumulation in macrophages by inhibiting FOXO1-mediated transcription of fatty acid-binding protein 4. Biochem Biophys Res Commun, 2010; 393: 89-94

23) Garin-Shkolnik T, Rudich A, Hotamisligil GS, Rubinstein M: FABP4 attenuates PPARgamma and adipogenesis and is inversely correlated with PPARgamma in adipose tissues. Diabetes, 2014; 63: 900-911

24) Ross SR, Graves RA, Greenstein A, Platt KA, Shyu HL, Mellovitz B, Spiegelman BM: A fat-specific enhancer is the primary determinant of gene expression for adipocyte P2 in vivo. Proc Natl Acad Sci U S A, 1990; 87: 9590-9594

25) Tontonoz P, Hu E, Graves RA, Budavari AI, Spiegelman BM: mPPAR gamma 2: tissue-specific regulator of an adipocyte enhancer. Genes Dev, 1994; 8: 1224-1234

26) Christy RJ, Yang VW, Ntambi JM, Geiman DE, Landschulz WH, Friedman AD, Nakabeppu Y, Kelly TJ, Lane MD: Differentiation-induced gene expression in 3T3-L1 preadipocytes: CCAAT/enhancer binding protein interacts with and activates the promoters of two adipocytespecific genes. Genes Dev, 1989; 3: 1323-1335

27) Rauscher FJ, 3rd, Sambucetti LC, Curran T, Distel RJ, Spiegelman BM: Common DNA binding site for Fos protein complexes and transcription factor AP-1. Cell, 1988; 52: 471-480

28) Tuncman G, Erbay E, Hom X, De Vivo I, Campos H, Rimm EB, Hotamisligil GS: A genetic variant at the fatty acid-binding protein $\mathrm{aP} 2$ locus reduces the risk for hypertriglyceridemia, type 2 diabetes, and cardiovascular disease. Proc Natl Acad Sci U S A, 2006; 103: 69706975

29) Elmasri H, Karaaslan C, Teper Y, Ghelfi E, Weng M, Ince TA, Kozakewich H, Bischoff J, Cataltepe S: Fatty acid binding protein 4 is a target of VEGF and a regulator of cell proliferation in endothelial cells. FASEB J, 2009; 23: 3865-3873

30) Elmasri H, Ghelfi E, Yu CW, Traphagen S, Cernadas M, Cao H, Shi GP, Plutzky J, Sahin M, Hotamisligil G, Cataltepe S: Endothelial cell-fatty acid binding protein 4 promotes angiogenesis: role of stem cell factor/c-kit pathway. Angiogenesis, 2012; 15: 457-468

31) Ha MK, Soo Cho J, Baik OR, Lee KH, Koo HS, Chung KY: Caenorhabditis elegans as a screening tool for the endothelial cell-derived putative aging-related proteins detected by proteomic analysis. Proteomics, 2006; 6: 3339-3351

32) Lee MY, Wang Y, Vanhoutte PM: Senescence of cultured porcine coronary arterial endothelial cells is associated with accelerated oxidative stress and activation of $\mathrm{NFkB}$. J Vasc Res, 2010; 47: 287-298

33) Lee MY, Tse HF, Siu CW, Zhu SG, Man RY, Vanhoutte
PM: Genomic changes in regenerated porcine coronary arterial endothelial cells. Arterioscler Thromb Vasc Biol, 2007; 27: 2443-2449

34) Fuseya T, Furuhashi M, Matsumoto M, Watanabe Y, Hoshina K, Mita T, Ishimura S, Tanaka M, Miura T: Ectopic Fatty Acid-Binding Protein 4 Expression in the Vascular Endothelium is Involved in Neointima Formation After Vascular Injury. J Am Heart Assoc, 2017; 6:

35) Furuhashi M, Fuseya T, Murata M, Hoshina K, Ishimura S, Mita T, Watanabe Y, Omori A, Matsumoto M, Sugaya T, Oikawa T, Nishida J, Kokubu N, Tanaka M, Moniwa N, Yoshida H, Sawada N, Shimamoto K, Miura T: Local Production of Fatty Acid-Binding Protein 4 in Epicardial/Perivascular Fat and Macrophages Is Linked to Coronary Atherosclerosis. Arterioscler Thromb Vasc Biol, 2016; 36: 825-834

36) Ayers SD, Nedrow KL, Gillilan RE, Noy N: Continuous nucleocytoplasmic shuttling underlies transcriptional activation of PPARgamma by FABP4. Biochemistry, 2007; 46: 6744-6752

37) Gillilan RE, Ayers SD, Noy N: Structural basis for activation of fatty acid-binding protein 4. J Mol Biol, 2007; 372: 1246-1260

38) Smith AJ, Sanders MA, Juhlmann BE, Hertzel AV, Bernlohr DA: Mapping of the hormone-sensitive lipase binding site on the adipocyte fatty acid-binding protein (AFABP). Identification of the charge quartet on the AFABP/aP2 helix-turn-helix domain. J Biol Chem, 2008; 283: 33536-33543

39) Scheja L, Makowski L, Uysal KT, Wiesbrock SM, Shimshek DR, Meyers DS, Morgan M, Parker RA, Hotamisligil GS: Altered insulin secretion associated with reduced lipolytic efficiency in aP2-/- mice. Diabetes, 1999; 48: 1987-1994

40) Shen WJ, Sridhar K, Bernlohr DA, Kraemer FB: Interaction of rat hormone-sensitive lipase with adipocyte lipid-binding protein. Proc Natl Acad Sci U S A, 1999; 96: $5528-5532$

41) Hofer P, Boeszoermenyi A, Jaeger D, Feiler U, Arthanari $\mathrm{H}$, Mayer N, Zehender F, Rechberger G, Oberer M, Zimmermann R, Lass A, Haemmerle G, Breinbauer R, Zechner R, Preiss-Landl K: Fatty Acid-binding Proteins Interact with Comparative Gene Identification-58 Linking Lipolysis with Lipid Ligand Shuttling. J Biol Chem, 2015; 290: 18438-18453

42) Walenna NF, Kurihara Y, Chou B, Ishii K, Soejima T, Itoh R, Shimizu A, Ichinohe T, Hiromatsu K: Chlamydia pneumoniae exploits adipocyte lipid chaperone FABP4 to facilitate fat mobilization and intracellular growth in murine adipocytes. Biochem Biophys Res Commun, 2018; 495: 353-359

43) Thompson BR, Mazurkiewicz-Munoz AM, Suttles J, Carter-Su C, Bernlohr DA: Interaction of adipocyte fatty acid-binding protein (AFABP) and JAK2: AFABP/ aP2 as a regulator of JAK2 signaling. J Biol Chem, 2009; 284: 13473-13480

44) Gorbenko O, Panayotou G, Zhyvoloup A, Volkova D, Gout I, Filonenko V: Identification of novel PTENbinding partners: PTEN interaction with fatty acid binding protein FABP4. Mol Cell Biochem, 2010; 337: 299-305 
45) Tsuda M, Inoue-Narita T, Suzuki A, Itami S, Blumenberg M, Manabe M: Induction of gene encoding FABP4 in Pten-null keratinocytes. FEBS Lett, 2009; 583: 13191322

46) Hotamisligil GS, Johnson RS, Distel RJ, Ellis R, Papaioannou VE, Spiegelman BM: Uncoupling of obesity from insulin resistance through a targeted mutation in aP2, the adipocyte fatty acid binding protein. Science, 1996; 274: 1377-1379

47) Uysal KT, Scheja L, Wiesbrock SM, Bonner-Weir S, Hotamisligil GS: Improved glucose and lipid metabolism in genetically obese mice lacking aP2. Endocrinology, 2000; 141: 3388-3396

48) Yang R, Castriota G, Chen Y, Cleary MA, Ellsworth K, Shin MK, Tran JL, Vogt TF, Wu M, Xu S, Yang X, Zhang BB, Berger JP, Qureshi SA: RNAi-mediated germline knockdown of FABP4 increases body weight but does not improve the deranged nutrient metabolism of diet-induced obese mice. Int J Obes (Lond), 2011; 35: 217-225

49) Boord JB, Maeda K, Makowski L, Babaev VR, Fazio S, Linton MF, Hotamisligil GS: Adipocyte fatty acid-binding protein, aP2, alters late atherosclerotic lesion formation in severe hypercholesterolemia. Arterioscler Thromb Vasc Biol, 2002; 22: 1686-1691

50) Makowski L, Brittingham KC, Reynolds JM, Suttles J, Hotamisligil GS: The fatty acid-binding protein, aP2, coordinates macrophage cholesterol trafficking and inflammatory activity. Macrophage expression of aP2 impacts peroxisome proliferator-activated receptor gamma and IkappaB kinase activities. J Biol Chem, 2005; 280: 12888-12895

51) Hui X, Li H, Zhou Z, Lam KS, Xiao Y, Wu D, Ding K, Wang Y, Vanhoutte PM, Xu A: Adipocyte fatty acidbinding protein modulates inflammatory responses in macrophages through a positive feedback loop involving c-Jun NH2-terminal kinases and activator protein-1. J Biol Chem, 2010; 285: 10273-10280

52) Steen KA, Xu H, Bernlohr DA: FABP4/aP2 Regulates Macrophage Redox Signaling and Inflammasome Activation via Control of UCP2. Mol Cell Biol, 2017; 37:

53) Xu H, Hertzel AV, Steen KA, Bernlohr DA: Loss of Fatty Acid Binding Protein 4/aP2 Reduces Macrophage Inflammation Through Activation of SIRT3. Mol Endocrinol, 2016; 30: 325-334

54) Cao H, Sekiya M, Ertunc ME, Burak MF, Mayers JR, White A, Inouye K, Rickey LM, Ercal BC, Furuhashi M, Tuncman G, Hotamisligil GS: Adipocyte lipid chaperone AP2 is a secreted adipokine regulating hepatic glucose production. Cell Metab, 2013; 17: 768-778

55) Mita T, Furuhashi M, Hiramitsu S, Ishii J, Hoshina K, Ishimura S, Fuseya T, Watanabe Y, Tanaka M, Ohno K, Akasaka H, Ohnishi H, Yoshida H, Saitoh S, Shimamoto K, Miura T: FABP4 is secreted from adipocytes by adenyl cyclase-PKA- and guanylyl cyclase-PKG-dependent lipolytic mechanisms. Obesity (Silver Spring), 2015; 23: 359-367

56) Ertunc ME, Sikkeland J, Fenaroli F, Griffiths G, Daniels MP, Cao H, Saatcioglu F, Hotamisligil GS: Secretion of fatty acid binding protein aP2 from adipocytes through a nonclassical pathway in response to adipocyte lipase activity. J Lipid Res, 2015; 56: 423-434

57) Schlottmann I, Ehrhart-Bornstein M, Wabitsch M, Bornstein SR, Lamounier-Zepter V: Calcium-dependent release of adipocyte fatty acid binding protein from human adipocytes. Int J Obes (Lond), 2014; 38: 1221 1227

58) Lamounier-Zepter V, Look C, Alvarez J, Christ T, Ravens U, Schunck WH, Ehrhart-Bornstein M, Bornstein SR, Morano I: Adipocyte fatty acid-binding protein suppresses cardiomyocyte contraction: a new link between obesity and heart disease. Circ Res, 2009; 105: 326-334

59) Kralisch S, Ebert T, Lossner U, Jessnitzer B, Stumvoll M, Fasshauer M: Adipocyte fatty acid-binding protein is released from adipocytes by a non-conventional mechanism. Int J Obes (Lond), 2014; 38: 1251-1254

60) Nickel W, Rabouille C: Mechanisms of regulated unconventional protein secretion. Nat Rev Mol Cell Biol, 2009; 10: 148-155

61) Villeneuve J, Bassaganyas L, Lepreux S, Chiritoiu M, Costet P, Ripoche J, Malhotra V, Schekman R: Unconventional secretion of FABP4 by endosomes and secretory lysosomes. J Cell Biol, 2018; 217: 649-665

62) Furuhashi M, Fucho R, Gorgun CZ, Tuncman G, Cao H, Hotamisligil GS: Adipocyte/macrophage fatty acidbinding proteins contribute to metabolic deterioration through actions in both macrophages and adipocytes in mice. J Clin Invest, 2008; 118: 2640-2650

63) Bosquet A, Guaita-Esteruelas S, Saavedra P, RodriguezCalvo R, Heras M, Girona J, Masana L: Exogenous FABP4 induces endoplasmic reticulum stress in HepG2 liver cells. Atherosclerosis, 2016; 249: 191-199

64) Wu LE, Samocha-Bonet D, Whitworth PT, Fazakerley DJ, Turner N, Biden TJ, James DE, Cantley J: Identification of fatty acid binding protein 4 as an adipokine that regulates insulin secretion during obesity. Mol Metab, 2014; 3: 465-473

65) Guaita-Esteruelas S, Bosquet A, Saavedra P, Guma J, Girona J, Lam EW, Amillano K, Borras J, Masana L: Exogenous FABP4 increases breast cancer cell proliferation and activates the expression of fatty acid transport proteins. Mol Carcinog, 2017; 56: 208-217

66) Furukawa S, Fujita T, Shimabukuro M, Iwaki M, Yamada Y, Nakajima Y, Nakayama O, Makishima M, Matsuda M, Shimomura I: Increased oxidative stress in obesity and its impact on metabolic syndrome. J Clin Invest, 2004; 114: 1752-1761

67) Saavedra P, Girona J, Bosquet A, Guaita S, Canela N, Aragones G, Heras M, Masana L: New insights into circulating FABP4: Interaction with cytokeratin 1 on endothelial cell membranes. Biochim Biophys Acta, 2015; 1853: 2966-2974

68) Martinez-Micaelo N, Rodriguez-Calvo R, Guaita-Esteruelas S, Heras M, Girona J, Masana L: Extracellular FABP4 uptake by endothelial cells is dependent on cytokeratin 1 expression. Biochim Biophys Acta Mol Cell Biol Lipids, 2018;

69) Shrestha S, Sunaga H, Hanaoka H, Yamaguchi A, Kuwahara S, Umbarawan Y, Nakajima K, Machida T, Murakami M, Saito A, Tsushima Y, Kurabayashi M, Iso T: Circulating FABP4 is eliminated by the kidney via 
glomerular filtration followed by megalin-mediated reabsorption. Sci Rep, 2018; 8: 16451

70) Ishimura S, Furuhashi M, Watanabe Y, Hoshina K, Fuseya T, Mita T, Okazaki Y, Koyama M, Tanaka M, Akasaka H, Ohnishi H, Yoshida H, Saitoh S, Miura T: Circulating levels of fatty acid-binding protein family and metabolic phenotype in the general population. PLoS One, 2013; 8: e81318

71) Xu A, Wang Y, Xu JY, Stejskal D, Tam S, Zhang J, Wat NM, Wong WK, Lam KS: Adipocyte fatty acid-binding protein is a plasma biomarker closely associated with obesity and metabolic syndrome. Clin Chem, 2006; 52: 405-413

72) Hu X, Ma X, Pan X, Luo Y, Xu Y, Xiong Q, Bao Y, Jia W: Association of androgen with gender difference in serum adipocyte fatty acid binding protein levels. Sci Rep, 2016; 6: 27762

73) Iso T, Sunaga H, Matsui H, Kasama S, Oshima N, Haruyama H, Furukawa N, Nakajima K, Machida T, Murakami M, Yokoyama T, Kurabayashi M: Serum levels of fatty acid binding protein 4 and fat metabolic markers in relation to catecholamines following exercise. Clin Biochem, 2017; 50: 896-902

74) Choi KM, Kim TN, Yoo HJ, Lee KW, Cho GJ, Hwang TG, Baik SH, Choi DS, Kim SM: Effect of exercise training on A-FABP, lipocalin-2 and RBP4 levels in obese women. Clin Endocrinol (Oxf), 2009; 70: 569574

75) Simon I, Escote X, Vilarrasa N, Gomez J, FernandezReal JM, Megia A, Gutierrez C, Gallart L, Masdevall C, Vendrell J: Adipocyte fatty acid-binding protein as a determinant of insulin sensitivity in morbid-obese women. Obesity (Silver Spring), 2009; 17: 1124-1128

76) Terra X, Quintero Y, Auguet T, Porras JA, Hernandez M, Sabench F, Aguilar C, Luna AM, Del Castillo D, Richart $\mathrm{C}$ : FABP 4 is associated with inflammatory markers and metabolic syndrome in morbidly obese women. Eur J Endocrinol, 2011; 164: 539-547

77) Fisher RM, Eriksson P, Hoffstedt J, Hotamisligil GS, Thorne A, Ryden M, Hamsten A, Arner P: Fatty acid binding protein expression in different adipose tissue depots from lean and obese individuals. Diabetologia, 2001; 44: 1268-1273

78) Lee JJ, Britton KA, Pedley A, Massaro JM, Speliotes EK, Murabito JM, Hoffmann U, Ingram C, Keaney JF, Jr., Vasan RS, Fox CS: Adipose Tissue Depots and Their Cross-Sectional Associations With Circulating Biomarkers of Metabolic Regulation. J Am Heart Assoc, 2016; 5 :

79) Wajchenberg BL: Subcutaneous and visceral adipose tissue: their relation to the metabolic syndrome. Endocr Rev, 2000; 21: 697-738

80) Miehle K, Ebert T, Kralisch S, Hoffmann A, Kratzsch J, Schlogl H, Stumvoll M, Fasshauer M: Adipocyte and epidermal fatty acid-binding protein serum concentrations in patients with lipodystrophy. Cytokine, 2017; 92: 20-23

81) Carlsson AC, Ingelsson E, Sundstrom J, Carrero JJ, Gustafsson S, Feldreich T, Stenemo M, Larsson A, Lind L, Arnlov J: Use of Proteomics To Investigate Kidney Function Decline over 5 Years. Clin J Am Soc Nephrol, 2017; 12: $1226-1235$
82) Furuhashi M, Ishimura $S$, Ota $H$, Hayashi $M$, Nishitani T, Tanaka M, Yoshida H, Shimamoto K, Hotamisligil GS, Miura T: Serum fatty acid-binding protein 4 is a predictor of cardiovascular events in end-stage renal disease. PLoS One, 2011; 6: e27356

83) Xu A, Tso AW, Cheung BM, Wang Y, Wat NM, Fong $\mathrm{CH}$, Yeung DC, Janus ED, Sham PC, Lam KS: Circulating adipocyte-fatty acid binding protein levels predict the development of the metabolic syndrome: a 5-year prospective study. Circulation, 2007; 115: 1537-1543

84) Nakamura R, Okura T, Fujioka Y, Sumi K, Matsuzawa K, Izawa S, Ueta E, Kato M, Taniguchi SI, Yamamoto K: Serum fatty acid-binding protein 4 (FABP4) concentration is associated with insulin resistance in peripheral tissues, A clinical study. PLoS One, 2017; 12: e0179737

85) Tso AW, Xu A, Sham PC, Wat NM, Wang Y, Fong CH, Cheung BM, Janus ED, Lam KS: Serum adipocyte fatty acid binding protein as a new biomarker predicting the development of type 2 diabetes: a 10-year prospective study in a Chinese cohort. Diabetes Care, 2007; 30: 2667-2672

86) Ota H, Furuhashi M, Ishimura S, Koyama M, Okazaki Y, Mita T, Fuseya T, Yamashita T, Tanaka M, Yoshida H, Shimamoto K, Miura T: Elevation of fatty acid-binding protein 4 is predisposed by family history of hypertension and contributes to blood pressure elevation. Am J Hypertens, 2012; 25: 1124-1130

87) Cabre A, Lazaro I, Girona J, Manzanares JM, Marimon F, Plana N, Heras M, Masana L: Plasma fatty acid binding protein 4 is associated with atherogenic dyslipidemia in diabetes. J Lipid Res, 2008; 49: 1746-1751

88) Yeung DC, Xu A, Cheung CW, Wat NM, Yau MH, Fong CH, Chau MT, Lam KS: Serum adipocyte fatty acid-binding protein levels were independently associated with carotid atherosclerosis. Arterioscler Thromb Vasc Biol, 2007; 27: 1796-1802

89) Fuseya T, Furuhashi M, Yuda S, Muranaka A, Kawamukai M, Mita T, Ishimura S, Watanabe Y, Hoshina K, Tanaka M, Ohno K, Akasaka H, Ohnishi H, Yoshida H, Saitoh S, Shimamoto K, Miura T: Elevation of circulating fatty acid-binding protein 4 is independently associated with left ventricular diastolic dysfunction in a general population. Cardiovasc Diabetol, 2014; 13: 126

90) Rodriguez-Calvo R, Girona J, Alegret JM, Bosquet A, Ibarretxe D, Masana L: Role of the fatty acid-binding protein 4 in heart failure and cardiovascular disease. J Endocrinol, 2017; 233: R173-R184

91) Nishino T, Okamoto K: Mechanistic insights into xanthine oxidoreductase from development studies of candidate drugs to treat hyperuricemia and gout. J Biol Inorg Chem, 2015; 20: 195-207

92) Furuhashi $M$, Matsumoto $M$, Tanaka M, Moniwa N, Murase T, Nakamura T, Ohnishi H, Saitoh S, Shimamoto K, Miura T: Plasma Xanthine Oxidoreductase Activity as a Novel Biomarker of Metabolic Disorders in a General Population. Circ J, 2018; 82: 1892-1899

93) Furuhashi M, Mori K, Tanaka M, Maeda T, Matsumoto M, Murase T, Nakamura T, Koyama M, Moniwa N, Ohnishi H, Saitoh S, Shimamoto K, Miura T: Unexpected high plasma xanthine oxidoreductase activity in female subjects with low levels of uric acid. Endocr J, 
2018; 65: 1083-1092

94) Furuhashi M, Matsumoto M, Murase T, Nakamura T, Higashiura Y, Koyama M, Tanaka M, Moniwa N, Ohnishi H, Saitoh S, Shimamoto K, Miura T: Independent links between plasma xanthine oxidoreductase activity and levels of adipokines. J Diabetes Investig, 2018 Dec 5. doi: 10.1111/jdi.12982. [Epub ahead of print]

95) Furuhashi M, Omori A, Matsumoto M, Kataoka Y, Tanaka M, Moniwa N, Ohnishi H, Yoshida H, Saitoh S, Shimamoto K, Miura T: Independent Link Between Levels of Proprotein Convertase Subtilisin/Kexin Type 9 and FABP4 in a General Population Without Medication. Am J Cardiol, 2016; 118: 198-203

96) Furuhashi M, Yuda S, Muranaka A, Kawamukai M, Matsumoto M, Tanaka M, Moniwa N, Ohnishi H, Saitoh S, Shimamoto K, Miura T: Circulating Fatty Acid-Binding Protein 4 Concentration Predicts the Progression of Carotid Atherosclerosis in a General Population Without Medication. Circ J, 2018; 82: 1121-1129

97) von Eynatten M, Breitling LP, Roos M, Baumann M, Rothenbacher D, Brenner $\mathrm{H}$ : Circulating adipocyte fatty acid-binding protein levels and cardiovascular morbidity and mortality in patients with coronary heart disease: a 10-year prospective study. Arterioscler Thromb Vasc Biol, 2012; 32: 2327-2335

98) Chow WS, Tso AW, Xu A, Yuen MM, Fong CH, Lam TH, Lo SV, Tse HF, Woo YC, Yeung CY, Cheung BM, Lam KS: Elevated circulating adipocyte-fatty acid binding protein levels predict incident cardiovascular events in a community-based cohort: a 12-year prospective study. J Am Heart Assoc, 2013; 2: e004176

99) Liu G, Ding M, Chiuve SE, Rimm EB, Franks PW, Meigs JB, Hu FB, Sun Q: Plasma Levels of Fatty AcidBinding Protein 4, Retinol-Binding Protein 4, HighMolecular-Weight Adiponectin, and Cardiovascular Mortality Among Men With Type 2 Diabetes: A 22-Year Prospective Study. Arterioscler Thromb Vasc Biol, 2016; 36: 2259-2267

100) Szasz T, Webb RC: Perivascular adipose tissue: more than just structural support. Clin Sci (Lond), 2012; 122: $1-12$

101) Numaguchi R, Furuhashi M, Matsumoto M, Sato H, Yanase Y, Kuroda Y, Harada R, Ito T, Higashiura Y, Koyama M, Tanaka M, Moniwa N, Nakamura M, Doi H, Miura T, Kawaharada N: Differential phenotypes in perivascular adipose tissue surrounding the internal thoracic artery and diseased coronary artery. J Am Heart Assoc, 2019; 8: e011147

102) Vural B, Atalar F, Ciftci C, Demirkan A, SusleyiciDuman B, Gunay D, Akpinar B, Sagbas E, Ozbek U, Buyukdevrim AS: Presence of fatty-acid-binding protein 4 expression in human epicardial adipose tissue in metabolic syndrome. Cardiovasc Pathol, 2008; 17: 392-398

103) Elie A, Bloksgaard M, Sun WY, Yang K, Man AWC, Xu A, Irmukhamedov A, Riber LP, Wang Y, De Mey JGR: Local enrichment of fatty acid-binding protein 4 in the pericardial cavity of cardiovascular disease patients. PLoS One, 2018; 13: e0206802

104) Obokata M, Iso T, Ohyama Y, Sunaga H, Kawaguchi T, Matsui H, Iizuka T, Fukuda N, Takamatsu H, Koitabashi N, Funada R, Takama N, Kasama S, Kaneko Y,
Yokoyama T, Murakami M, Kurabayashi M: Early increase in serum fatty acid binding protein 4 levels in patients with acute myocardial infarction. Eur Heart J Acute Cardiovasc Care, 2018; 7: 561-569

105) Karpisek M, Stejskal D, Kotolova H, Kollar P, Janoutova G, Ochmanova R, Cizek L, Horakova D, Yahia RB, Lichnovska R, Janout V: Treatment with atorvastatin reduces serum adipocyte-fatty acid binding protein value in patients with hyperlipidaemia. Eur J Clin Invest, 2007; 37: 637-642

106) Furuhashi M, Mita T, Moniwa N, Hoshina K, Ishimura S, Fuseya T, Watanabe Y, Yoshida H, Shimamoto K, Miura T: Angiotensin II receptor blockers decrease serum concentration of fatty acid-binding protein 4 in patients with hypertension. Hypertens Res, 2015; 38: 252-259

107) Cabre A, Lazaro I, Girona J, Manzanares JM, Marimon F, Plana N, Heras M, Masana L: Fatty acid binding protein 4 is increased in metabolic syndrome and with thiazolidinedione treatment in diabetic patients. Atherosclerosis, 2007; 195: e150-158

108) Furuhashi M, Matsumoto M, Hiramitsu S, Omori A, Tanaka M, Moniwa N, Yoshida H, Ishii J, Miura T: Possible Increase in Serum FABP4 Level Despite Adiposity Reduction by Canagliflozin, an SGLT2 Inhibitor. PLoS One, 2016; 11: e0154482

109) Iso T, Maeda K, Hanaoka H, Suga T, Goto K, Syamsunarno MR, Hishiki T, Nagahata Y, Matsui H, Arai M, Yamaguchi A, Abumrad NA, Sano M, Suematsu M, Endo K, Hotamisligil GS, Kurabayashi M: Capillary endothelial fatty acid binding proteins 4 and 5 play a critical role in fatty acid uptake in heart and skeletal muscle. Arterioscler Thromb Vasc Biol, 2013; 33: 25492557

110) Han Q, Yeung SC, Ip MSM, Mak JCW: Effects of intermittent hypoxia on A-/E-FABP expression in human aortic endothelial cells. Int J Cardiol, 2010; 145: 396398

111) Hwang HH, Moon PG, Lee JE, Kim JG, Lee W, Ryu $\mathrm{SH}$, Baek MC: Identification of the target proteins of rosiglitazone in 3T3-L1 adipocytes through proteomic analysis of cytosolic and secreted proteins. Mol Cells, 2011; 31: 239-246

112) Tanaka M, Furuhashi M, Okazaki Y, Mita T, Fuseya T, Ohno K, Ishimura S, Yoshida H, Miura T: Ectopic expression of fatty acid-binding protein 4 in the glomerulus is associated with proteinuria and renal dysfunction. Nephron Clin Pract, 2014; 128: 345-351

113) Yao F, Li Z, Ehara T, Yang L, Wang D, Feng L, Zhang Y, Wang K, Shi Y, Duan H, Zhang L: Fatty Acid-Binding Protein 4 mediates apoptosis via endoplasmic reticulum stress in mesangial cells of diabetic nephropathy. Mol Cell Endocrinol, 2015; 411: 232-242

114) Kamijo A, Kimura K, Sugaya T, Yamanouchi M, Hikawa A, Hirano N, Hirata Y, Goto A, Omata M: Urinary fatty acid-binding protein as a new clinical marker of the progression of chronic renal disease. J Lab Clin Med, 2004; 143: 23-30

115) Okazaki Y, Furuhashi M, Tanaka M, Mita T, Fuseya T, Ishimura S, Watanabe Y, Hoshina K, Akasaka H, Ohnishi $\mathrm{H}$, Yoshida H, Saitoh S, Shimamoto K, Miura T: 
Urinary excretion of fatty acid-binding protein 4 is associated with albuminuria and renal dysfunction. PLoS One, 2014; 9: e115429

116) Ghelfi E, Karaaslan C, Berkelhamer S, Akar S, Kozakewich H, Cataltepe S: Fatty acid-binding proteins and peribronchial angiogenesis in bronchopulmonary dysplasia. Am J Respir Cell Mol Biol, 2011; 45: 550-556

117) Maver A, Medica I, Peterlin B: Search for sarcoidosis candidate genes by integration of data from genomic, transcriptomic and proteomic studies. Med Sci Monit, 2009; 15: SR22-28

118) Shum BO, Mackay CR, Gorgun CZ, Frost MJ, Kumar RK, Hotamisligil GS, Rolph MS: The adipocyte fatty acid-binding protein $\mathrm{aP} 2$ is required in allergic airway inflammation. J Clin Invest, 2006; 116: 2183-2192

119) Ghelfi E, Yu CW, Elmasri H, Terwelp M, Lee CG, Bhandari V, Comhair SA, Erzurum SC, Hotamisligil GS, Elias JA, Cataltepe S: Fatty acid binding protein 4 regulates VEGF-induced airway angiogenesis and inflammation in a transgenic mouse model: implications for asthma. Am J Pathol, 2013; 182: 1425-1433

120) Ge XN, Bastan I, Dileepan M, Greenberg Y, Ha SG, Steen KA, Bernlohr DA, Rao SP, Sriramarao P: FABP4 regulates eosinophil recruitment and activation in allergic airway inflammation. Am J Physiol Lung Cell Mol Physiol, 2018; 315: L227-L240

121) Duffy CM, Xu H, Nixon JP, Bernlohr DA, Butterick TA: Identification of a fatty acid binding protein4UCP2 axis regulating microglial mediated neuroinflammation. Mol Cell Neurosci, 2017; 80: 52-57

122) Saint-Geniez M, Ghelfi E, Liang X, Yu C, Spencer C, Abend S, Hotamisligil G, Cataltepe S: Fatty acid binding protein 4 deficiency protects against oxygen-induced retinopathy in mice. PLoS One, 2014; 9: e96253

123) Wang Q, Shi G, Teng Y, Li X, Xie J, Shen Q, Zhang C, Ni S, Tang Z: Successful reduction of inflammatory responses and arachidonic acid-cyclooxygenase 2 pathway in human pulmonary artery endothelial cells by silencing adipocyte fatty acid-binding protein. J Inflamm (Lond), 2017; 14: 8

124) Hu B, Guo Y, Garbacz WG, Jiang M, Xu M, Huang H, Tsung A, Billiar TR, Ramakrishnan SK, Shah YM, Lam KS, Huang M, Xie W: Fatty acid binding protein-4 (FABP4) is a hypoxia inducible gene that sensitizes mice to liver ischemia/reperfusion injury. J Hepatol, 2015; 63: 855-862

125) Scifres CM, Chen B, Nelson DM, Sadovsky Y: Fatty acid binding protein 4 regulates intracellular lipid accumulation in human trophoblasts. J Clin Endocrinol Metab, 2011; 96: E1083-1091

126) Nourani MR, Owada Y, Kitanaka N, Sakagami H, Hoshi H, Iwasa H, Spener F, Kondo H: Occurrence of immunoreactivity for adipocyte-type fatty acid binding protein in degenerating granulosa cells in atretic antral follicles of mouse ovary. J Mol Histol, 2005; 36: 491497

127) $\mathrm{Hu}$ W, Qiao J: Expression and regulation of adipocyte fatty acid binding protein in granulosa cells and its relation with clinical characteristics of polycystic ovary syndrome. Endocrine, 2011; 40: 196-202

128) Nieman KM, Kenny HA, Penicka CV, Ladanyi A, Buell-
Gutbrod R, Zillhardt MR, Romero IL, Carey MS, Mills GB, Hotamisligil GS, Yamada SD, Peter ME, Gwin K, Lengyel E: Adipocytes promote ovarian cancer metastasis and provide energy for rapid tumor growth. Nat Med, 2011; 17: 1498-1503

129) Gharpure KM, Pradeep S, Sans M, Rupaimoole R, Ivan C, Wu SY, Bayraktar E, Nagaraja AS, Mangala LS, Zhang X, Haemmerle M, Hu W, Rodriguez-Aguayo C, McGuire M, Mak CSL, Chen X, Tran MA, Villar-Prados A, Pena GA, Kondetimmanahalli R, Nini R, Koppula P, Ram P, Liu J, Lopez-Berestein G, Baggerly K, L SE, Sood AK: FABP4 as a key determinant of metastatic potential of ovarian cancer. Nat Commun, 2018; 9: 2923

130) Bennett JH, Shousha S, Puddle B, Athanasou NA: Immunohistochemical identification of tumours of adipocytic differentiation using an antibody to aP2 protein. J Clin Pathol, 1995; 48: 950-954

131) Cataltepe O, Arikan MC, Ghelfi E, Karaaslan C, Ozsurekci Y, Dresser K, Li Y, Smith TW, Cataltepe S: Fatty acid binding protein 4 is expressed in distinct endothelial and non-endothelial cell populations in glioblastoma. Neuropathol Appl Neurobiol, 2012; 38: 400-410

132) Ohlsson G, Moreira JM, Gromov P, Sauter G, Celis JE: Loss of expression of the adipocyte-type fatty acid-binding protein (A-FABP) is associated with progression of human urothelial carcinomas. Mol Cell Proteomics, 2005; 4: 570-581

133) Kim S, Lee Y, Koo JS: Differential expression of lipid metabolism-related proteins in different breast cancer subtypes. PLoS One, 2015; 10: e0119473

134) Cha YJ, Kim HM, Koo JS: Expression of Lipid Metabolism-Related Proteins Differs between Invasive Lobular Carcinoma and Invasive Ductal Carcinoma. Int J Mol Sci, 2017; 18:

135) Huang M, Narita S, Inoue T, Koizumi A, Saito M, Tsuruta $H$, Numakura K, Satoh S, Nanjo H, Sasaki T, Habuchi T: Fatty acid binding protein 4 enhances prostate cancer progression by upregulating matrix metalloproteinases and stromal cell cytokine production. Oncotarget, 2017; 8: 111780-111794

136) Thompson KJ, Austin RG, Nazari SS, Gersin KS, Iannitti DA, McKillop IH: Altered fatty acid-binding protein 4 (FABP4) expression and function in human and animal models of hepatocellular carcinoma. Liver Int, 2018; 38: 1074-1083

137) Zhong CQ, Zhang XP, Ma N, Zhang EB, Li JJ, Jiang YB, Gao YZ, Yuan YM, Lan SQ, Xie D, Cheng SQ: FABP4 suppresses proliferation and invasion of hepatocellular carcinoma cells and predicts a poor prognosis for hepatocellular carcinoma. Cancer Med, 2018; 7: 26292640

138) Chiyonobu N, Shimada S, Akiyama Y, Mogushi K, Itoh M, Akahoshi K, Matsumura S, Ogawa K, Ono H, Mitsunori Y, Ban D, Kudo A, Arii S, Suganami T, Yamaoka S, Ogawa Y, Tanabe M, Tanaka S: Fatty Acid Binding Protein 4 (FABP4) Overexpression in Intratumoral Hepatic Stellate Cells within Hepatocellular Carcinoma with Metabolic Risk Factors. Am J Pathol, 2018; 188: 1213-1224

139) Lee D, Wada K, Taniguchi Y, Al-Shareef H, Masuda T, 
Usami Y, Aikawa T, Okura M, Kamisaki Y, Kogo M: Expression of fatty acid binding protein 4 is involved in the cell growth of oral squamous cell carcinoma. Oncol Rep, 2014; 31: 1116-1120

140) Jin J, Zhang Z, Zhang S, Chen X, Chen Z, Hu P, Wang J, Xie C: Fatty acid binding protein 4 promotes epithelial-mesenchymal transition in cervical squamous cell carcinoma through AKT/GSK3beta/Snail signaling pathway. Mol Cell Endocrinol, 2018; 461: 155-164

141) Tang Z, Shen Q, Xie H, Zhou X, Li J, Feng J, Liu H, Wang W, Zhang S, Ni S: Elevated expression of FABP3 and FABP4 cooperatively correlates with poor prognosis in non-small cell lung cancer (NSCLC). Oncotarget, 2016; 7: 46253-46262

142) Sulsky R, Magnin DR, Huang Y, Simpkins L, Taunk P, Patel M, Zhu Y, Stouch TR, Bassolino-Klimas D, Parker R, Harrity T, Stoffel R, Taylor DS, Lavoie TB, Kish K, Jacobson BL, Sheriff S, Adam LP, Ewing WR, Robl JA: Potent and selective biphenyl azole inhibitors of adipocyte fatty acid binding protein (aFABP). Bioorg Med Chem Lett, 2007; 17: 3511-3515

143) Furuhashi M, Tuncman G, Gorgun CZ, Makowski L, Atsumi G, Vaillancourt E, Kono K, Babaev VR, Fazio S, Linton MF, Sulsky R, Robl JA, Parker RA, Hotamisligil GS: Treatment of diabetes and atherosclerosis by inhibiting fatty-acid-binding protein aP2. Nature, 2007; 447: 959-965

144) Hertzel AV, Hellberg K, Reynolds JM, Kruse AC, Juhlmann BE, Smith AJ, Sanders MA, Ohlendorf DH, Suttles J, Bernlohr DA: Identification and characterization of a small molecule inhibitor of Fatty Acid binding proteins. J Med Chem, 2009; 52: 6024-6031

145) Miao X, Wang Y, Wang W, Lv X, Wang M, Yin H: The $\mathrm{mAb}$ against adipocyte fatty acid-binding protein $2 \mathrm{E} 4$ attenuates the inflammation in the mouse model of high-fat diet-induced obesity via toll-like receptor 4 pathway. Mol Cell Endocrinol, 2015; 403: 1-9

146) Burak MF, Inouye KE, White $A$, Lee $A$, Tuncman $G$, Calay ES, Sekiya M, Tirosh A, Eguchi K, Birrane G, Lightwood D, Howells L, Odede G, Hailu H, West S, Garlish R, Neale H, Doyle C, Moore A, Hotamisligil GS: Development of a therapeutic monoclonal antibody that targets secreted fatty acid-binding protein aP2 to treat type 2 diabetes. Sci Transl Med, 2015; 7: 319ra205

147) Simpson MA, LiCata VJ, Ribarik Coe N, Bernlohr DA: Biochemical and biophysical analysis of the intracellular lipid binding proteins of adipocytes. Mol Cell Biochem, 1999; 192: 33-40

148) Yu CW, Liang X, Lipsky S, Karaaslan C, Kozakewich H, Hotamisligil GS, Bischoff J, Cataltepe S: Dual role of fatty acid-binding protein 5 on endothelial cell fate: a potential link between lipid metabolism and angiogenic responses. Angiogenesis, 2016; 19: 95-106

149) Feingold KR, Kazemi MR, Magra AL, McDonald CM, Chui LG, Shigenaga JK, Patzek SM, Chan ZW, Londos C, Grunfeld C: ADRP/ADFP and Mal1 expression are increased in macrophages treated with TLR agonists. Atherosclerosis, 2010; 209: 81-88

150) Maeda K, Uysal KT, Makowski L, Gorgun CZ, Atsumi G, Parker RA, Bruning J, Hertzel AV, Bernlohr DA, Hotamisligil GS: Role of the fatty acid binding protein mal1 in obesity and insulin resistance. Diabetes, 2003; 52: 300-307

151) Hertzel AV, Bennaars-Eiden A, Bernlohr DA: Increased lipolysis in transgenic animals overexpressing the epithelial fatty acid binding protein in adipose cells. J Lipid Res, 2002; 43: 2105-2111

152) Babaev VR, Runner RP, Fan D, Ding L, Zhang Y, Tao H, Erbay E, Gorgun CZ, Fazio S, Hotamisligil GS, Linton MF: Macrophage Mal1 deficiency suppresses atherosclerosis in low-density lipoprotein receptor-null mice by activating peroxisome proliferator-activated receptorgamma-regulated genes. Arterioscler Thromb Vasc Biol, 2011; 31: 1283-1290

153) Yamamoto T, Furuhashi M, Sugaya T, Oikawa T, Matsumoto M, Funahashi Y, Matsukawa Y, Gotoh M, Miura T: Transcriptome and Metabolome Analyses in Exogenous FABP4- and FABP5-Treated Adipose-Derived Stem Cells. PLoS One, 2016; 11: e0167825

154) Yeung DC, Wang Y, Xu A, Cheung SC, Wat NM, Fong DY, Fong CH, Chau MT, Sham PC, Lam KS: Epidermal fatty-acid-binding protein: a new circulating biomarker associated with cardio-metabolic risk factors and carotid atherosclerosis. Eur Heart J, 2008; 29: 21562163

155) Furuhashi M, Ogura M, Matsumoto M, Yuda S, Muranaka A, Kawamukai M, Omori A, Tanaka M, Moniwa N, Ohnishi H, Saitoh S, Harada-Shiba M, Shimamoto K, Miura T: Serum FABP5 concentration is a potential biomarker for residual risk of atherosclerosis in relation to cholesterol efflux from macrophages. Sci Rep, 2017; 7: 217

156) Maeda K, Cao H, Kono K, Gorgun CZ, Furuhashi M, Uysal KT, Cao Q, Atsumi G, Malone H, Krishnan B, Minokoshi Y, Kahn BB, Parker RA, Hotamisligil GS: Adipocyte/macrophage fatty acid binding proteins control integrated metabolic responses in obesity and diabetes. Cell Metab, 2005; 1: 107-119

157) Cao H, Maeda K, Gorgun CZ, Kim HJ, Park SY, Shulman GI, Kim JK, Hotamisligil GS: Regulation of metabolic responses by adipocyte/macrophage Fatty Acidbinding proteins in leptin-deficient mice. Diabetes, 2006; 55: 1915-1922

158) Boord JB, Maeda K, Makowski L, Babaev VR, Fazio S, Linton MF, Hotamisligil GS: Combined adipocyte-macrophage fatty acid-binding protein deficiency improves metabolism, atherosclerosis, and survival in apolipoprotein E-deficient mice. Circulation, 2004; 110: 1492 1498

159) Anderson RM, Weindruch R: Metabolic reprogramming, caloric restriction and aging. Trends Endocrinol Metab, 2010; 21: 134-141

160) Charles KN, Li MD, Engin F, Arruda AP, Inouye K, Hotamisligil GS: Uncoupling of Metabolic Health from Longevity through Genetic Alteration of Adipose Tissue Lipid-Binding Proteins. Cell Rep, 2017; 21: 393-402

161) Syamsunarno MR, Iso $T$, Hanaoka $H$, Yamaguchi $A$, Obokata M, Koitabashi N, Goto K, Hishiki T, Nagahata Y, Matsui H, Sano M, Kobayashi M, Kikuchi O, Sasaki T, Maeda K, Murakami M, Kitamura T, Suematsu M, Tsushima Y, Endo K, Hotamisligil GS, Kurabayashi M: A critical role of fatty acid binding protein 4 and 5 
(FABP 4/5) in the systemic response to fasting. PLoS One, 2013; 8: e79386

162) Syamsunarno MR, Iso $T$, Yamaguchi $A$, Hanaoka $H$, Putri M, Obokata M, Sunaga H, Koitabashi N, Matsui H, Maeda K, Endo K, Tsushima Y, Yokoyama T, Kurabayashi M: Fatty acid binding protein 4 and 5 play a crucial role in thermogenesis under the conditions of fasting and cold stress. PLoS One, 2014; 9: e90825

163) Cao H, Gerhold K, Mayers JR, Wiest MM, Watkins SM, Hotamisligil GS: Identification of a lipokine, a lipid hormone linking adipose tissue to systemic metabolism. Cell, 2008; 134: 933-944

164) Erbay E, Babaev VR, Mayers JR, Makowski L, Charles KN, Snitow ME, Fazio S, Wiest MM, Watkins SM, Linton MF, Hotamisligil GS: Reducing endoplasmic reticulum stress through a macrophage lipid chaperone alleviates atherosclerosis. Nat Med, 2009; 15: 1383-1391

165) Coleman SL, Park YK, Lee JY: Unsaturated fatty acids repress the expression of adipocyte fatty acid binding protein via the modulation of histone deacetylation in RAW 264.7 macrophages. Eur J Nutr, 2011; 50: 323330

166) Cimen I, Kocaturk B, Koyuncu S, Tufanli O, Onat UI, Yildirim AD, Apaydin O, Demirsoy S, Aykut ZG,
Nguyen UT, Watkins SM, Hotamisligil GS, Erbay E: Prevention of atherosclerosis by bioactive palmitoleate through suppression of organelle stress and inflammasome activation. Sci Transl Med, 2016; 8: 358ra126

167) Stefan N, Kantartzis K, Celebi N, Staiger H, Machann J, Schick F, Cegan A, Elcnerova M, Schleicher E, Fritsche A, Haring HU: Circulating palmitoleate strongly and independently predicts insulin sensitivity in humans. Diabetes Care, 2010; 33: 405-407

168) Mozaffarian D, Cao H, King IB, Lemaitre RN, Song $X$, Siscovick DS, Hotamisligil GS: Trans-palmitoleic acid, metabolic risk factors, and new-onset diabetes in U.S. adults: a cohort study. Ann Intern Med, 2010; 153: 790799

169) Berger WT, Ralph BP, Kaczocha M, Sun J, Balius TE, Rizzo RC, Haj-Dahmane S, Ojima I, Deutsch DG: Targeting fatty acid binding protein (FABP) anandamide transporters - a novel strategy for development of antiinflammatory and anti-nociceptive drugs. PLoS One, 2012; 7: e50968

170) Wang YT, Liu CH, Zhu HL: Fatty acid binding protein (FABP) inhibitors: a patent review (2012-2015). Expert Opin Ther Pat, 2016; 26: 767-776 